\title{
The Musaeum: Its Contents
}

\subsection{Introduction}

When Strada in 1568 thanked Duke Guglielmo of Mantua for the benefice conferred on his elder son Paolo, he offered the use of his house to the Duke, providing a brief description of its contents and adding that 'most of these things have been seen by all those gentlemen of the court of Your Excellency that have been here [in Vienna].' ${ }^{1}$ This confirms the accessibility of Strada's Musaeum and the representative function it fulfilled. To have any idea of the impact the Musaeum had on such visitors, it is useful to provide a quick sketch of its contents.

A sketch, an impression: not a reconstruction. There are a number of sources which give a very elementary impression of what Strada's studiolo may have looked like, and there are some other sources which give slightly more concrete information on which specific objects, or type of objects, passed through his hands. Some of these-in particular the large-scale acquisitions of antique sculpture for the Duke of Bavaria in 1566-1569-were certainly not intended for Strada's own collection, and they did never even come to Vienna. In most cases the information is too scanty to identify objects mentioned with any certainty, or to determine what their destination was. We just do not know whether Strada bought them on behalf of the Emperor, whether he bought them on commission from other patrons, whether he bought them on speculationthat is as a true art-dealer, hoping to sell them to the visitors of his house or dispose of them advantageously in some other way—or whether he bought them after all just for his own collection.

For this reason, except for Strada's acquisitions for the Duke of Bavaria, in the following no distinction will be made between the objects that may have belonged to Strada's private collection, and those that he bought or commissioned for a patron or intended as stock-in-trade. After all, in each of these cases the presence of these objects, their availability in Vienna, could influence those who-in the case of antiquities and works of art—saw and admired them, and those who-in the case of the manuscripts, the printed books and the graphic documentation-consulted or even studied them. The works of art incited the patron's appetite for these or similar works; they modified the taste

1 Doc. 1568-12-28, quoted more fully below.

(C) DIRK JACOB JANSEN, 2019 | DOI:10.1163/9789004359499_014

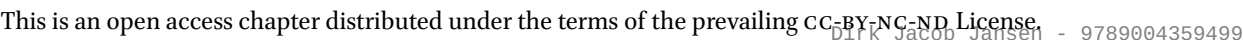


of the individual patron more or less incisively and changed the fashion generally current at court. Moreover they stimulated the artists working at or in the orbit of the Imperial court by providing authoritative examples of up-to-date styles and artistic techniques and a storehouse of compositional 'inventions'.

\subsection{Strada's Own Descriptions of His Musaeum}

In Strada's letter to Jacopo Dani describing the entertainment he had planned to offer Riccardo Riccardi, had he come to visit Strada's house, he not only mentioned the company, but also briefly enumerates the many objects of interest that Riccardi had missed seeing:

I also wished to show him my house, which can stand comparison with any of those beautiful houses of Italy, and which cost me over twelve thousand Thaler. I also wanted to show him my medals, which, though they are not many, they are nevertheless most exquisite; and then with these also my collection ['studio'] of most excellent antiquities and paintings; then my most ample and complete library, full of books in all the sciences and in all languages. So you will see that he would not have ill spent that day. ${ }^{2}$

Much earlier Strada had advertised his collection in a letter thanking Duke Guglielmo of Mantua for having conferred a benefice in Mantua Cathedral on his eldest son, Paolo Strada. ${ }^{3}$ Almost as a counter present he offered the Duke the use of his house in exchange, 'at any occasion that you might have need of it, which, once finished, is suitable to lodge a prince'. He then continues with a slightly more detailed description of part of its contents:

There is also something in [my house] to pass the time: I have a library that exceeds three thousand volumes, among which there are a great number in Hebrew (I can say all the principal ones that have been printed). In manuscript there are a good number in several languages. I don't want to pass over that there are more than fifty written in Arabic, which I prize most highly for having unearthed them from Turkey with great difficulty and at great expense; and every day I continue to enrich my library with all sorts of books.

2 Doc. 1581-11-02.

3 Doc. $1568-12-28$. 
I also possess a beautiful choice of antique medals, together with a book of drawings of them, which begins at the reign of Nerva and ends at that of Alexander Severus, the son of Julia Mammea. This book was judged by Pope Julius del Monte [Pope Julius III], my patron, and by all the Cardinals that saw it at that time, the most beautiful and made with the greatest judgment they had ever seen. The same was thought in France and in Germany; the most excellent Lord Duke of Ferrara, when he found himself in my house together with Count Francesco da Novellara likewise confirmed the opinion of the other Princes mentioned here.

In my library there are thirteen big volumes of descriptions of medals that have been seen by me wherever I have been in the world: they count over twelve thousand descriptions.

There are also seven big volumes of antique inscriptions that I have collected, and lately I have added to them those [found] in Turkey, in Egypt and in Hungary, and in all the lands [now] occupied by the Turks.

At present in my house is written a Dictionary of eleven languages, which is a task at which I have laboured for eighteen years, during which I always have maintained people at work at it. These are the languages: Latin, Greek, Hebrew, Chaldean, Turkish, Arabic, Persian, Spanish, French, German and Italian; and at the appropriate places I insert [images of] the medals, marble statues, epitaphs, and whatever else it is possible to show in pictures.

Many other things I have here, which in great part have been seen by those gentlemen from the court of Your Excellency that have passed by here; which, in order not to take up any more of your time, I do not want to mention all here. All these things I offer to Your Excellency; should you wish to avail yourself of this, I am at your command; and when my books will be finished Your Excellency will have his part of them.

A few years later Strada offered to present his collections, which he indicated as his 'khunstkamer' to the Elector August of Saxony, as a gift in exchange for a pension for himself and his children. For this he gave two reasons: on the one hand because, at his advanced age, he was often subject to diseases and he was afraid that after his death his collection might end up in the wrong hands; on the other hand because he hoped that work on the immense illustrated dictionary he was preparing could thus continue under the aegis of the Elector. ${ }^{4}$ He gave a brief description which is worth quoting:

4 The letter only survives in a German translation made at the Dresden court: Doc. 1575-09-28, published and first commented in Lietzmann 1997 (Dokument 2), pp. 396-397. 
Illustrious Prince! For over twenty years and more I have brought together a cabinet of curiosities ['khunstkamer'] together with a library, and know for certain that at present no lord in Germany has its equal, except for his Highness [the Duke] of Bavaria. Therefore his Roman Imperial Majesty has often come to me with other princes to inspect it. I have saved no expense: whenever I saw something delightful, be it manuscript or printed books, be it antiquities, medals and beautiful paintings, I have bought them to add to the collection $<$... >Such paintings and the casts of the portrait heads of Emperors and Empresses, which I have brought together from all over Italy, together with wonderful books written by hand in the Arabic, Turkish, Persian, Greek and Latin languages, cannot be found anywhere but in my [collection]. And it also includes all the books in Hebrew that have ever been printed, and a great number of Latin and Greek books, many thousands of volumes. Your Electoral Graces's secretary, Herr Jeniss, can give Your Electoral Grace a report of it, for he has seen it all at the time Your Electoral Grace was here in Vienna. Since that time I have augmented it for at least three thousand Thaler, both with new books and antiquities and beautiful medals. Your Electoral Grace will find it a beautiful treasure.

Strada's letter was presented by his son-in-law, probably the Ferdinand Lützelburger or Luzenburger who is mentioned in his will as the husband of his daughter Lavina, and it was accompanied by what Strada described as a 'small gift', but which in fact was rather splendid, for it also served to thank the Elector for the subvention he had earlier accorded Strada for his multilingual Dictionary. It consisted of the twelve copies of the portraits of the first twelve Emperors painted by Titian for the Camerino dei Cesari in the Ducal palace at Mantua, which Strada had commissioned from Giorgio Molinarolo in 1567, and which appears to have been originally intended for his own studio, rather than for one of his patrons. ${ }^{5}$

The Elector appears not to have accepted this present-it may have come too expensive in view of the counter-gift to which this would have obliged him—for in the next years we see Strada make various other attempts to sell

5 Ibidem; on these paintings, see below; Dorothea Diemer, 'Mantua in Bayern? Eine Planungsepisode der Münchner Kunstkammer', in Diemer/Diemer/Sauerländer 2008, 3, pp. 320-329. Lietzmann 1997, who published the letter and relating documents, suggests that Strada's 'glane presenz' consisted of drawings after these paintings, but that is not warranted by the text, which explicitly speaks of works 'painted in oils'. Moreover 'Il Cerragagno', Stopio's correspondent, explicitly relates that Strada had had copied (by Giorgio Molinarolo) both Giulio's scenes and Titian's portraits themselves; but the latter cannot have been intended for Munich, where a set of copies of Titian's emperors by Campi was already available. 
his house and collection in order to obtain the funds to finish his Dictionary and other publishing projects, going even so far as to try and make a lottery of it. All these efforts were wasted, for in his last will of 1583 he again determines that after his death the collection should be presented to some unspecified patron, and part of the proceeds used to finance the printing of his books. ${ }^{6}$

Though slightly varying according to their addressee, these three letters basically conform in their description of Strada's collection. This consisted of three principal components: a collection of antiquities, a collection of contemporary works of art, and a library. Neither the inventories Strada appears to have made in his lifetime, for his own use and that of his patrons, nor the settlement agreed among his heirs after his death have been preserved. ${ }^{7}$ To get a hint of the contents of the various sections we have to rely on the sparse concrete data provided by disparate contemporary and slightly later sourceschief among these the documents preserved in Munich relating to Strada's acquisitions for Duke Albrecht V of Bavaria. These will be the subject of the following paragraph.

\subsection{Strada's Acquisitions for Duke Albrecht v of Bavaria}

Whereas Strada's role as an architect has been referred to only very casually in earlier literature, reason why it was treated more extensively in the preceding chapters, his role as an agent or merchant of works of art in general, and of classical antiquities in particular, has always been considered a central element in his career. There can be no doubt that Strada himself considered it as such, witness the great pride with which, in the dedication to Duke Albrecht V of his edition of Caesar's Commentaries (Frankfurt 1575), he described his acquisition - on behalf of Hans Jakob Fugger and the Duke himself-of the huge collection of classical statuary that filled the Munich Antiquarium:

6 'Doc 1584-07-01; discussed in greater detail below, Ch. 14.9. I have found no indication to which patron Strada referred with the term 'Bewissten Ort'.

7 Strada refers to an inventory in his letter to Vilém z Rožmberka (Doc. 1573-12-18): 'Euer Gnaden weren ein Inventari haben von meiner Liberay unndt Kunstkhamer, die ich Dero geben hab, wie Sie in meinem Haus gebesen sent, damals Euer Gnaden on mich begertt hatt; unndt Sich darinnen wol wissen zu erinnern, in was Gelt ichs Euer Gnaden ongeslagen hab'. But when he offered his Kunstkammer to August of Saxony (Doc. 1575-09-28) he had no upto-date inventory available: 'Ich hett darneben Eur C.F.G. gern ein Inventari der picher als wol der antiquitethen ges[c]higt, so ist es des dings so fil, das mir die zeitt zu kurz ist worden'. The copy of Strada's testament preserved in the Österreichische Nationalbibliothek carries an annotation 'die Vergleichung der Bruedern und Schwestern vide in S'-unfortunately that document has not been preserved. The testament was opened only on September 28, 1590, a year and a half after Strada's death. 
Over twenty years ago I was sent to Italy, to Rome and Venice and elsewhere, to buy gold, silver and bronze coins, as well as old and important marbles, which with great effort and expense of money I brought to Augsburg, divesting Italy of its most noble spoils. Among these are several heads of Emperors and Empresses, moreover many intact marble statues, and other works of no less prize and antiquity.<... $>$ In the same way I have bought up, during two trips I made into Italy, to Venice, the most famous Musaeum of the Venetian nobleman Andrea Loredan, in which can be seen the most beautiful heads in marble as well as in bronze, intact marble statues, and ancient coins of all sorts, which he had brought together as occasion served for over fifty years and at great expense. These, together with many other most noble works of the same kind, which would be too long to mention here, I had brought to Munich, at the cost of many thousands of ducats $<\ldots . . .^{8}$

Strada's employment by Hans Jakob Fugger has already been discussed in chapter 3 . The sources relating to the activities he now deployed, at Fugger's recommendation, on behalf of the collections of Duke Albrecht V, confirm the important place such traffic in works of art and antiquities had among Strada's occupations. $^{9}$

\subsubsection{Sources: The Libri Antiquitatum and the Letters of Niccolò Stopio}

The most important source documenting the formation of these collections consists of a number of files preserved in the Bayerisches Hauptstaatsarchiv in Munich. These Libri Antiquitatum, containing correspondence, accounts, some inventories and miscellaneous material, have been known and consulted since at least the end of the eighteenth century, and some extensive extracts have been published, though not always with great precision. ${ }^{10}$ The material directly relating to Strada's commissions is to be found in the first three volumes, which contain some of his letters to the Duke and to Fugger, drafts of their answers, some accounts, lists of available objects and other miscellanea. Moreover, the second volume contains the letters from Venice written by another agent employed by Fugger on behalf of the Duke, the Italianate

$8 \quad$ Caesar 1575 , fol. * 4 .

9 The following paragraph is a slightly expanded and updated version of my article 'Jacopo Strada et le Commerce d'Art', in Revue de l'Art (Jansen 1987).

10 München, Bayerisches Hauptstaatsarchiv, Kurbayern, Äusseres Archiv 4851-4856; here after referred to as BHStA-LA 4851-4856); extracts published in Stockbauer 1874 (passim) and used extensively throughout Von Busch 1973; Weski/Frosien-Leinz 1987 and Diemer/ Diemer/Sauerländer 2008. 
Flemish poet and erudite Niccolò Stopio. ${ }^{11}$ Stopio's regular reports provide a lively, though rather one-sided impression of Strada's occupations during his sojourns in Venice, and it will therefore be useful briefly to sketch the context of this correspondence.

Though a native of Aalst, in the Southern Netherlands, Stopio had been resident in Venice for at least twenty years. ${ }^{12}$ He provided Hans Jakob Fugger with weekly news bulletins, in the spirit of the Fuggerzeitungen, and forwarded Fugger's correspondence to Bologna, Florence and Rome. He also purveyed books and manuscripts-in particular manuscripts from Greece, relatively easy to come by in Venice - and various luxury goods, such as gloves, soaps, and even medicines made after his own recipes. His real speciality seems to have been music: he not only sent instruments, but also contracted musicians and instrument makers for the Bavarian court. ${ }^{13}$ And as a neo-Latin poet, he wrote texts for Orlando di Lasso — such as the motet Gratia Sola Dei sung at the wedding, in 1568, of Prince Wilhelm of Bavaria to Renée of Lorraine-and for other composers at the Bavarian court. Thus he provided a laudatory poem on Duchess Anna that was set to five voices for the same occasion by Caterina, the gifted daughter of Adriaen Willaert. ${ }^{14}$ Though obviously neither wealthy nor particularly illustrious, he appears to have been respected as a man of letters, and to have been at least acquainted with most of Venice's leading artists and literati. Yet it is clear that he strongly resented the contrast between his position and that of Strada, whom he claimed to have known in different circumstances many years earlier.

11 BHStA-LA 4851, $485^{2}$ (Stopio's correspondence) and 4853.

12 On Stopio, see Von Busch 1973, pp. 116, n. 48. The Biblioteca Ambrosiana in Milan preserves some of his poems in manuscript (Iter Italicum I, 1965, pp. 287, 302, 307). He provided all manner of services and goods, such as books, but also cosmetics and medicines, cf. BHStA-LA 4852, ff. 58, 49, 245 and 215: 'Mando con quella un libro delle cose di Carolo V, et un libretto del viaggio di Terra Santa, et doi pezzetti di sapone, biancho et verdetto<...>'.

13 These musicians were not always eager to remain in Germany: '<... >ma sopratutto comprendo che quel paese non fa per questi musici d'Italia, che sono tutti teste leggiere, et sono usi di stare con le loro compagne et putane, che è il loro Paradiso, a tal che partendo d'Italia pare che vadino al Purgatorio $<$... > et così quando uno vi è, cerca di persuadere al compagno chel ci venghi, poi concludono a non volervi stare ne l'uno ne l'altro<...>', ibid., ff. 71-72; on musical instruments, ibid. f. 64 .

14 'Gratia sola Dei pie in omnibus in omnia adimplet', in: Peter Bergquist [ed.], Orlando Di Lasso: The Complete Motets, 7, Madison (WI) 1998, p. xvii and p. xxvii (its text and an English translation). On Caterina Willaert's madrigal, see Massimo Troiano, Dialoghi<...> ne' quali si narrano le cose piu notabili fatte nelle nozze dello illustriss. et eccell. prencipe Guglielmo VI., conte palatino del Reno, e duca di Baviera; e dell' illustriss. et eccell. madama Renata di Loreno, Venice 1569 , fols. 123v-124v. 
Though not in the first place considered as a man of letters, as was Stopio, Strada was a nobleman, was quite wealthy, held an officially recognized position in the first secular court of Christianity, and was reputedly considered to be among the finest antiquaries of Europe ${ }^{15} \mathrm{He}$ was, moreover, charged with a very lucrative commission which Stopio had had some illusions of securing for himself. As Strada appears also to have been rather overbearing, if not at times outright arrogant in manner, it is not really surprising that Stopio did not greatly take to him. But his dislike soon developed into a vicious envy of Strada's accomplishments and successes, and in his almost weekly reports to Fugger he left nothing unsaid which he thought might discredit Strada in the eyes of their common patron, and thus indirectly in those of Albrecht v. He accused Strada of paying exorbitant prices for the antiquities he acquired on behalf of the Duke; of a tactless highhandedness with the Venetian noblemen from whom he often made his purchases; and of a lack of professional judgment and general erudition. He even went to the childish extreme of reproving Strada for a supposed spelling mistake in one of his letters, and rubbed that in even in successive reports to Fugger ${ }^{16}$ Finally he dwelt on the low esteem which, he claimed, was accorded to Strada by the Venetians, and he contrasted this with Strada's high reputation on the other side of the Alps: being more reliable and more honourable - 'reali di natura' is Stopio's term - than the Italians, he explained, the Germans were more easily taken in. ${ }^{17}$

Stopio's negative judgment of Strada's character is known only from the few published excerpts from his correspondence, chiefly relating to Strada's dealings with Titian which have already been cited in my introduction. This may well be the reason why it has so often been taken at face value. This confidence

15 BHStA-LA 4852, f.15; ibid., f. 32: '<...>et tutto questo dico solo perchè Vostra Signoria [= Hans Jakob Fugger] mi scrisse già, chel è tenuto per uno de' primi antiquari intelligenti di Europa $<\ldots$. >'

16 BHStA-LA 4852, ff. 32, 62, 231, 280. That it was properly the word with which Strada declared himself Stopio's affectionate friend says something about the latter's character: '<...> et certo mi stupisco come un simil grossolone [= Strada] ha acquistato tanto credito in Alemagna, fra tali huomini dotti e giudiciosi; Vostra Signoria [= Hans Jakob Fugger] puo considerare la sua scientia in questa lettera ch'l m'a scritto di Mantua, dove in loco di affett. ${ }^{\text {mo }}$ scrive efitionatiss. ${ }^{\text {mo; }}$ chi vide mai simil ignorantia in persona chi fa professione di sapere, a non haver fin in questa sua età mai misso a mente il significato ne ortografia di tanto comune vocabolo<... >'. It is true that Strada's usage is very unusual—it cannot be found in the Vocabolario della Crusca - yet in general Strada's Italian, including his spelling, is polished, clear, elegant and self-assured: certainly not that of a 'grossolone'. Of course Fugger, a consummate speaker of Italian himself, was very well aware of that, and paid no attention to Stopio's ravings. 
is misplaced, as is clear not only from the vindictive tone of Stopio's correspondence as a whole, but also from the fact that Fugger, one of the most intelligent and discriminating patrons of the sixteenth century, almost completely ignored his insinuations. ${ }^{18}$ In the following an attempt will be made to cull from the correspondence the facts about Strada's activities in Venice, discarding Stopio's subjective interpretations of these, and to place them as much as possible within the context afforded by other sources.

\subsubsection{Acquisitions of Antiquities for Duke Albrecht $v$ of Bavaria}

Strongly influenced by the ideas and the example of his Hofkammerpräsident, Hans Jakob Fugger, who by this time had become the Duke's primary advisor in all artistic and intellectual matters, Albrecht $\mathrm{v}$ was bringing together at Munich a complex of collections expressly aimed to further the interests of the state as well as to serve the instruction and entertainment of the Prince and his immediate circle. This complex consisted of an encyclopaedic Kunstkammer, a large library, and a collection of antiquities of a scale and quality unique north of the Alps. For the Kunstkammer an accommodation had just been completed, while the library and the Antiquarium were to be housed in a second, specially designed building, the conception of which is, as we have seen in chapter 8 , largely due to Strada.

Strada's employment by the Duke was the direct and logical consequence of his earlier activities for Fugger. Strada had maintained his connection with Fugger after his appointment at the Imperial court, and it is likely that he continued to scout and buy antiquities for him. It can hardly be a coincidence that Fugger had been in Venice in 1560 and accompanied Strada when he first negotiated with the Venetian nobleman, Andrea Loredan, about the acquisition of part or all of his huge and very famous collection of antiquities for Emperor Ferdinand I, a deal which never materialized. ${ }^{19}$ Strada had been in Venice again in March 1562, when he provided and annotated an inventory of the smaller collection of Vincenzo del Gallo Bussoni, a list which is preserved in Munich with a German translation, doubtless provided by Fugger on the Duke's behalf. ${ }^{20}$ When Fugger ceded his own collections to the Duke, he persuaded him to employ Strada in the acquisition of additional antiquities in Italy.

18 In a letter dated Vienna 30 March 1569 (BHStA- $L A$ 4852, fols. 228 ff.) Fugger, at the time staying in Strada's house, refutes Stopio's accusations and sternly takes him to task for his own mistakes and omissions in his services to Fugger and Duke Albrecht, and stops responding to Stopio letters until the latter's sudden death a few months later.

19 Von Busch 1973, pp. 117-118.

$20 \quad$ BHStA-LA 4851, fol. 29; printed in Stockbauer 1874, pp. 44-48. 
Strada's first trip in the Duke's service, in 1566 , was to Rome, the obvious source of Roman antiquities. Here he purchased a considerable quantity of antique sculpture, which arrived in Munich only in the summer of 1567 . A list Strada had made when he was packing the crates, which in Munich was translated by Fugger himself, lists no less than twenty-five full-length statues, about thirty portrait heads, and a number of fragments and miscellaneous objects. ${ }^{21}$ Doubtless incited by Fugger and by Strada himself, in the following year the Duke sent Strada to Venice to attempt the purchase of the huge and famous collection of antiques brought together by Andrea Loredan. After complicated negotiations, involving a lawsuit and the intervention of the Signoria on behalf of the Duke, Strada was able to conclude the transaction during a second trip to Venice in $1568 .{ }^{22}$

The purchase included ninety-one portrait heads, forty-three statues and torsos, thirty-three reliefs, forty-four miscellaneous fragments of statuary, about hundred and twenty small bronzes and a quantity of other objects of archaeological interest, and finally a medal cabinet containing about 2500 gold, silver and bronze Greek and Roman coins. ${ }^{23}$ The original estimate of the collection amounted to about 8400 ducats, which the Duke was allowed to pay in yearly instalments. It can thus be regarded as the most important single transaction of Strada's career known to us. ${ }^{24}$

Apart from the Loredan collection Strada also vainly attempted to acquire part of the equally celebrated collection left by another Venetian nobleman, Gabriele Vendramin. He did, however, succeed in purchasing on behalf of the Duke a number of antiquities from the collection of Simone Zeno: twenty-two portrait heads, six small full-length statues or statuettes, seven torsos, fifteen

21 Von Busch 1973, pp. 116-17 and 139-141 ff.; BHStA-LA 4851, fols. 235, 248-249, 282-285; excerpts printed in Weski/Frosien-Leinz 1987, Textband, Quellenanhang pp. 457-459, nrs. $38-47$. The Roman sources on the exportation of antiques from Rome published in Jestaz 1963 do not refer to these acquisitions.

22 Strada is documented in Venice from February until the end of August 1567; from February until July 1568 (part of which time he spent in Mantua) and again briefly in July 1569; cf. Von Busch 1973, pp. 203-207.

23 Von Busch 1973, pp. 119-122 (on Strada's negotiations with Andrea Loredan) and pp. 142143 (on the contents of these collections).

24 Von Busch 1973, pp. 120-121. In financial terms, the transaction can only be compared in scope to the corpus of numismatic drawings Strada purveyed to Fugger and later to Duke Albrecht V: this included ca 8.000 drawings for which Strada was paid a ducat each (cf. above, Ch. 3.3). But this transaction stretched over at least two decades; cf. above, Ch. 3; and Von Busch 1973, pp. 194-195. The genesis of the collection of the Antiquarium has received ample attention in Von Busch 1973 and Weski/ Frosien-Leinz 1987, so need not be discussed here. 
bronzes and some miscellaneous objects. At 390 ducats for the lot, this was a relatively modest acquisition, as was, at 100 ducats, the lot of two statues, a bust and a sarcophagus he could buy from the heirs of Cardinal Pietro Bembo. While still in Venice Strada had one of Zeno's torsos completed with a head and an arm. ${ }^{25}$ His third trip to Venice, in 1569 , was made in order to negotiate the purchase of two numismatic collections, respectively belonging to Giulio Calestano of Milan and to Marco Mantova Benavides of Padua, and of a collection of cameos and antique intaglios. ${ }^{26}$ At the same time Strada remained on the alert for further items of potential interest to Albrecht $\mathrm{V}$, whom he provided with annotated inventories of available collections, and to whom he signalled individual pieces, such as the antique sculptures he saw in the house of Giulio Romano in Mantua and in the studio of the sculptor Alessandro Vittoria, in Venice. ${ }^{27}$

Two statues still in the Antiquarium that can be identified with items Strada had bought in Rome can serve as examples of his acquisitions. One is a Diana of Ephesus, described in a list of the statues sent to Munich in the summer of 1567 as:

A statue of Diane of the Ephesians, all intact and the figure decorated with histories, its head and hands are of black stone called 'paragona', and the statue is in white marble. This is as good as any of the best things found in Rome. ${ }^{28}$ [Fig. 12.1]

It was famous in its time, being drawn by Etienne du Pérac and Stephanus Vinandus Pighius as well as by Strada himself, who included it in his Statuarum antiquarum, an album of drawings from his workshop illustrating antique

25 On the Vendramin collection: BHStA-LA 4851, fols. 195 and 316; cf. Anderson 1979; on the collection Zeno: BHStA-LA 4853, fol. 132-15v. The works Strada acquired from the Zeno and Bembo collections are listed in the final account he presented to the Duke, BHStA- $L A$ 4853, fols. 11-21, published in Stockbauer 1874, pp. 32-36; Weski/Frosien-Leinz 1987, Textband, p. 464, nr. 109. On Pietro Cardinal Bembo's collection, see Eiche 1982, pp. 352-359.

26 BHStA-LA 4853, fol. 11. On the collection of Marco Mantova Benavides, see Favaretto 1972 and Candida 1967; Dacos 1969.

$27 \quad$ BHStA- $L A 4853$, fols. 11 and 27; Stockbauer 1874, p. 31.

28 BHStA-LA 4851, fol. 283 r/v (nr. o9): 'Una statua di Diana Efesia, tutta integra e tutta historiata la figura, la sua testa le mani e li piedi son di pietra negra cioe di paragone, e la statua sie di marmor bianco, questa sta al pari delle piu belle cose che sia in roma'. It is now interpreted as an Aphrodite of Aphrodisias; otherwise than Strada thought (or wished to communicate?) its face, hands (lost) and feet in black marble were contemporary restorations; cf. Weski/Frosien-Leinz 1987, Textband, pp. 312-313, cat. nr. 192 and pp. 428 , cat. nr. 341 . 

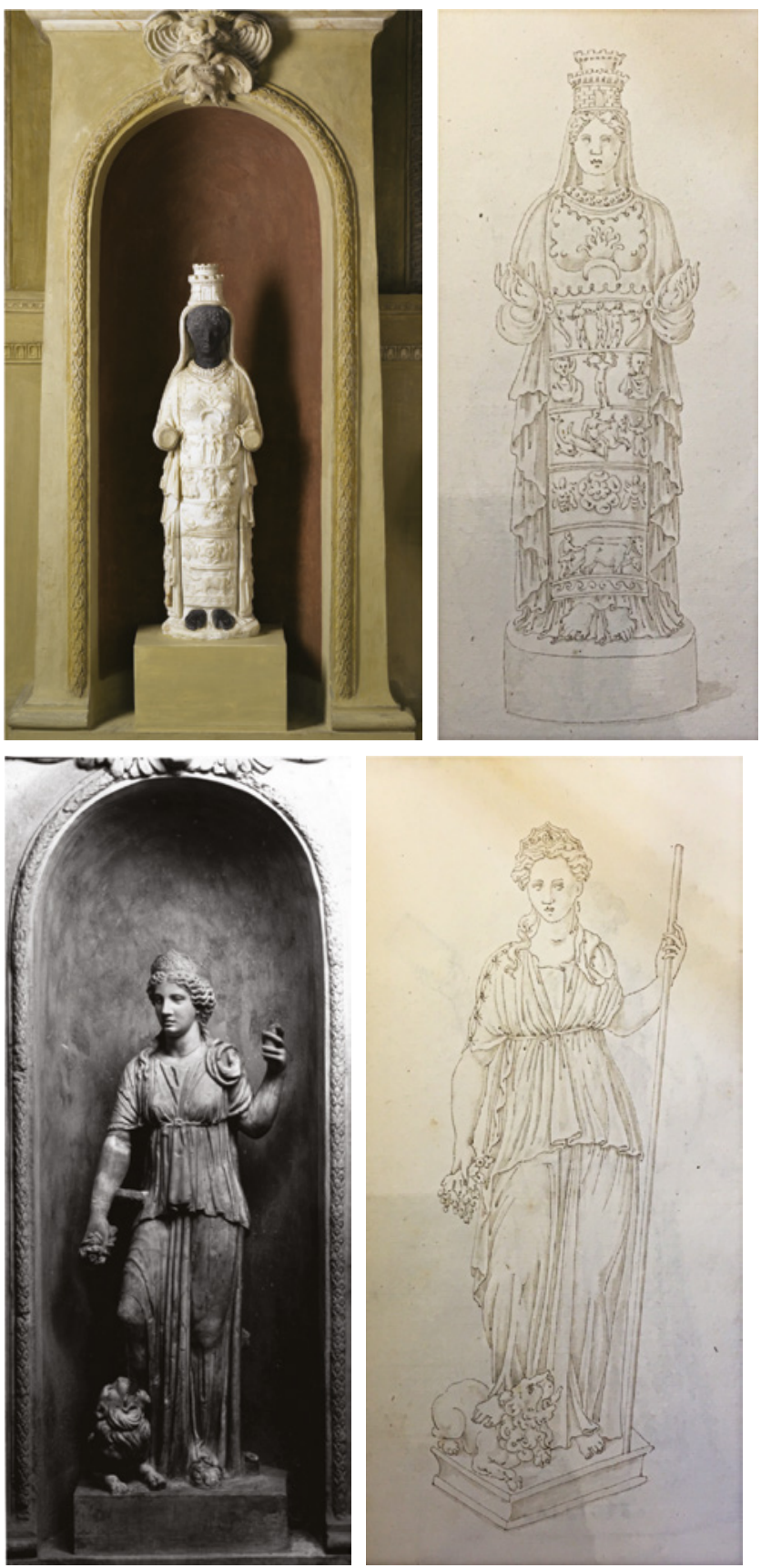

FIGURES 12.1-12.4 The Diana of Ephesus and the Cybele, among the statues acquired by Strada for the Munich Antiquarium that are still in situ; he included drawings of both in his ms. Statuarum antiquarum, Vienna, Österreichische Nationalbibliothek, Cod. min. 21,2. 
full-length statues that is preserved in the Österreichische Nationalbibliothek [Fig. 12.2] ${ }^{29}$ Another one is a relatively intact female statue restored in the midsixteenth century or earlier as a Cybele or-according to Strada - as an Asia [Fig. 12.3]. In Strada's list it is described as 'A small statue of Asia in full relief, slightly smaller than life size, with a lion under her feet', and he likewise included it in his Statuarum antiquarum [Fig. 12.4] ${ }^{30}$ Probably its restoration-the missing head was replaced-predates Strada's acquisition, though it remains possible that he had commissioned it himself, as he had done with the torso from the Zeno collection.

Strada did employ some local sculptors to execute some small restorations, among whom the best sculptor active in Venice, Alessandro Vittoria, from whom he also commissioned a Cupido all' antica. ${ }^{31} \mathrm{~A}$ year later he proposed the Duke to have some of the sculptures sent to Vienna, to have them restored under his direct supervision in his own house. As in his drawings of coins, such restorations doubtless would have included the replacement of missing parts, as was in any case the general practice in the sixteenth century. ${ }^{32}$ Though in his Statuarum antiquarum Strada does show statues with heads, hands or arms lacking, the general impression is that he preferred to represent his statues in a sufficiently intact — that is, restored — state, to convey their artistic intention.

This is certainly the case in the set of drawings of Roman portrait busts likewise preserved in Vienna, which are probably in Strada's own hand: it is unlikely that the originals still were all in the pristine condition in which Strada represents them [Fig. 12.5]. ${ }^{33}$ In particular the portrait heads, often found severed from their bodies, were intended to be complemented by a suitable bust made to measure by sculptors in Strada's pay. It is just possible that a rather flattened bust among the spolia of the fake Roman ruin in the park of Schönbrunn - it was probably intended to present a portrait head destined for

29 Antiquarum statuarum tam deorum, quam dearum heroum et eorum coniugum, tum etiam imperatorum et eorundem uxorum formae et effigies ex antiquis marmoreis et aeneis statuis, quae et Romae et aliis in locis inveniuntur ad vivum depictae atque fidelissime repraesentatae, Vienna, ÖNB-HS, Cod. min. 21,1, fol. 139; it is not mentioned in Weski/ Frosien-Leinz 1987, who illustrate Du Pérac's and Pighius' drawings (Textband pp. 429; p. 112-113, Abb. 99 (Du Pérac) and 100 (Codex Pighianus).

BHStA-LA 4851, fol. 283 r/v (nr. 22): 'Una statuetta di Asia di tutto tondo alquanto minore dell naturale con un lione sotto agli piedi'; Weski/Frosien-Leinz 1987, Textband, pp. 313-314, cat. nr. 193 and pp. 442, cat. nr. 364. The present head is a nineteenth-century replacement of an earlier (Renaissance?) restoration. Strada's drawing in his Antiquarum statuarum (cit.), fol. 34 .

31 Cf. below, Ch. 12.5.3.

32 Von Busch 1973, p. 131 and 146, 148-149; cf. below, Ch. 12.4.

33 önb-Hs, Cod. Min. 21,3, fols. 344/61r-362/7or. 

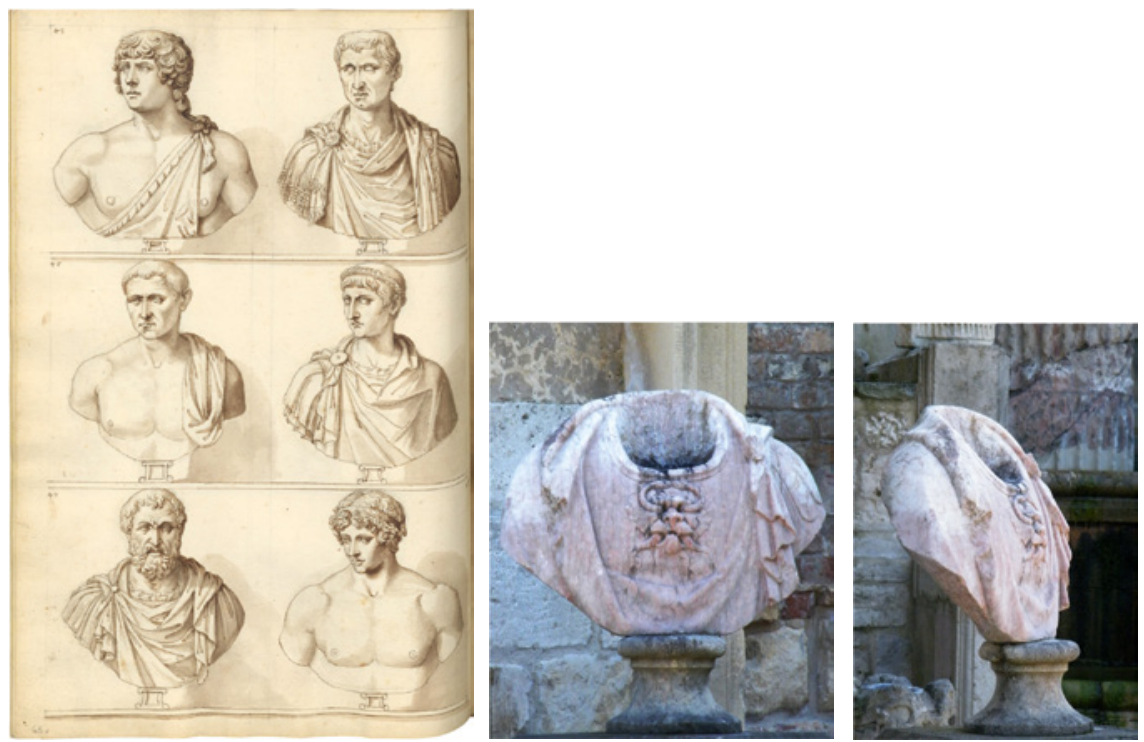

FIGURE 12.5

Jacopo Strada, drawings of (restored) antique portrait heads; Vienna, österreichsiche Nationalbibliothek, Cod. min. 21,3.

FIGURES 12.6-12.7 A marble bust originally made to present an antique portrait head and similar in type and function to those commissioned by Strada for the Antiquarium, as reused in the Römische Ruine at Schönbrunn.

a shallow niche - may be a relic of Strada's project to provide the Duke's portrait heads with busts made in his own workshop in Vienna [Figs. 12.6-12.7].$^{34}$

From the remaining correspondence it appears that in general Strada did not make purchases for the Duke until he received an explicit commission; yet these commissions were given in response to Strada's own proposals, based on his inspection of the various collections available in Rome and Venice. So at least in his dealings with the Bavarian court Strada acted as a scout and an agent, rather than as an independent dealer or merchant. Backed by the credit of both the Duke of Bavaria and Fugger, he was able to offer very high prices: too high, according to Cardinal Otto Truchsess von Waldburg, Prince-Bishop of Augsburg. But Truchsess wrote to Duke Albrecht from Rome, so his information was at second hand and probably based on the gossip started by Stopio. ${ }^{35}$

34 Von Busch 1973, pp. 146-148. In the end the busts for the portrait heads in the Antiquarium were made only some years later, and in Munich, not in Vienna: cf. Weski/FrosienLeinz 1987, Textband, pp.39-42 and Figs. 111-17.

Von Busch 1973, p. 297, n. 82. 
For such big acquisitions Strada relied upon the assistance of certain middlemen or 'Unterkäufer' (literally 'under-buyers') to assist him in his negotiations. Of the sensali, officially authorized valuers and brokers who were involved in the estimate of the Loredan collection, the knowledgeable Giovanni Battista Mondella seems to have been his most trusted adviser. Strada had got to know him during his visit of 1560 , when Mondella had acted as an intermediary when he acquired three statues from the Loredan collection. ${ }^{36}$

On the other hand it should be noted that Strada appears to have advanced part of the capital needed to pay for the acquisitions (excluding the Loredan collection, which was paid for directly through the Duke's commercial agent) and to cover various incidental expenses, as is clear from the account he later handed in. He did moreover occasionally buy antiquities on his own account: perhaps for some other, unidentified patrons, perhaps for his own collection. But it is not clear whether-apart from his own, private studio-he deliberately collected a large stock of ancient sculpture and other relics of Antiquity explicitly intended to supply potential customers such as Albrecht $\mathrm{V}$ at will; that is, whether he set up as a merchant of art on a grand scale.

Apart from the acquisitions themselves, Strada also occupied himself with other necessary activities in connection with the Duke's collection of antiquities. While still in Venice he already looked after the restoration of some of the sculptures, and he proposed that part of the Loredan marbles should be sent to Munich by way of Vienna, a considerable detour, where he intended to have them restored in his own studio and under his own direct supervision, as had been done with some of the statues from Rome. ${ }^{37}$ In Venice he ordered tablets in black marble or 'pietra di paragone' to be used for the inscriptions that were intended to be placed in the pedestals of the various statues. This was very critical work because the customary abbreviations in the Latin inscriptions could easily be garbled by unlettered stonecutters. Strada later insisted that it was necessary to have them made under his direct supervision, because even the few test examples he had had made in Venice by a first class master

36 Von Busch 1973, p. 118 and p. 291, n. 60 and 292, n. 64. Strada made use of Mondella also on other occasions, and employed him as his agent when he was absent from Venice. At Strada's request Duke Albrecht provided Mondella with a 'fede', a formal letter of recommendation, see BHStA, Kurbayern, A.A. 4853 [= LA 3], fols. 13, 83, 122 and 185. Foreign merchants in Venice were more or less obliged to uses such brokers in their dealings (cf. Welch 2005, pp. 33 ff.).

37 Von Busch 1973, p. 207; BHStA, Kurbayern, A.A. 4851 [= LA 2], fols. 309, 310 and 314. Some of the restorations were done in Venice by Alessandro Vittoria. The Duke declined Strada's offer, because he did not trust the statues to go to Vienna, considering Maximilian II a serious rival in the collecting of antique statuary. 
had not come out according to his instructions. ${ }^{38} \mathrm{He}$ also ordered several little chests, cabinets and cases on behalf of the Duke, which were intended to hold the coins and medals and perhaps also the cameos and intaglios. They were provided with very many drawers covered in red, green and blue morocco and lined with satin in the same colours-possibly so that the different types of objects could be easily distinguished, but more probably to systematically separate the gold, silver and bronze coins. ${ }^{39}$ Since Strada himself bought the materials and paid the craftsmen - two or three cabinet makers, a book binder and, probably, a woodcarver who prepared the ebony decoration of (most of) the drawers-it is likely that he not merely ordered these containers, but also provided the designs for them. ${ }^{40}$

Finally, as we have seen above, Strada was closely involved in the planning of the arrangement of the statues, first advising on the planned room for the antiquities in the Munich Kunstkammer, then being closely involved in the conception of the separate building that was planned to house both the Duke's antiques and his library, the Antiquarium of the Munich Residenz, for which Strada furnished an attractive Italianate design. It is clear that he was also

38 The work on the marble tablets is listed in Strada's final account, BHStA, Kurbayern, A.A. 4853 [= LA 3], fols. 11r-21v, printed in Stockbauer 1874, p. 32-36: 'Item zu Mantua um 28 Tafeln schwarze stein zu f 18 thut v 85 f 3 st $8 .<\ldots>$ Um die Schrift in einen schwarzen stein zu hauen v 3 f 1 st $8 .<\ldots>$ Die Buchstaben zu vergolden v 1 f 1 st 2 '. Fugger's notes for his meeting with Duke Albrecht after his consultation with Strada in Vienna in the summer of 1567 refers to the inscriptions: 'Also begert er [= Strada] im auch die schwarzen Stain hinab zue ordnen, damit er die Schrifften recht darein laß machen, dabei mieß er selb sein, dan unangesechen er drinnen ein guetten Maister gehabt, und er im die sachen under hand selb geben, hab er ain Stain dreimal verkhern miessen, das erst mal hab er im die Außthailung übl gmacht und ain ganze Zail ausgelassen, unangesehen er es ims auf Papir fürgemalt, das hab er im 2 Buechstaben ausgelassen, also daß er im auff den Stain hab miessen alles fürreissen, und hett im dannocht schier umb ain ganzen Buechstaben gefhelet, da er nit dabei gwest und gleich darzue kommen wer; dann dise Leut haben kain Juditium noch Verstand, man mieß alle Stund bei inen sein $<\ldots . .>$ ', BHStA, Kurbayern, A.A. 4852 [= LA 2], fols. 119r-121v, printed in Weski/Frosien Leinz 1987, Textband, p. 461, doc. 80.

39 This corresponds with the use of colours for different sections of a collection proposed by Quiccheberg, and practised for instance in Archduke Ferdinand's Kunstkammer at Ambras.

40 Strada's final account begins with an item 'Unkosten so über die Trühelein zu den Medaglien ergangen'(BHStA-LA 4853, fols. 11r; Stockbauer 1874, p. 32). The drawers of the medal chest were lined in green, red or blue silk or morocco, gilt, and in some cases decorated with ebony carved profiles; a small quantity of ivory mentioned may have been used for the small turned knobs to open the drawers. p. 32; cf. Von Busch 1973, pp.146-147. They are mentioned in Strada's letter from Mantua to Duke Albrecht: 'La casetta delle medaglie, l'una portaro con esso meco, le altre due si finiranno in mia absenza perchè e digià finito tutte le casettini dove vanno le medaglie dentro'. (Doc. 1567-07-12). 
expected to provide the master plan underlying the eventual collocation of Albrecht's acquisitions within the Antiquarium. ${ }^{41}$

Summing up it appears that, though he certainly was well paid for his endeavours, when antiquities were involved Strada's activities in Venice cannot really be compared with those of a modern art dealer. They have much more in common with the tasks of the professional curator of a large museum.

\subsection{Strada's Own Cabinet of Antiquities}

\subsubsection{The Cabinet as Shown in the Portrait}

The Italian collections that provided the antiquities Strada acquired first for Fugger and then for Duke Albrecht V of Bavaria also provided him with the objects he brought together in his own cabinet or Musaeum, though he probably had begun collecting these much earlier, perhaps as early as in Rome in the 1530s, and he must have made use of opportunities he encountered on his travels, for instance in Lyon. Except for his collection of ancient coins, which he always mentions separately, and which can be partially reconstructed on

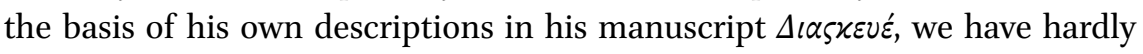
any positive evidence about the antiquarian contents of his Musaeum, except that it existed. Doubtless it included at least some marbles, some small antique bronzes and other objects, such as the antiquities Strada is showing off so enthusiastically in his portrait by Titian. Though these may be chiefly intended to refer to the acquisitions for Duke Albrecht $V$ of Bavaria in which Strada was engaged at that time, they are representative for the type of objects he was particularly interested in and must have bought for himself, and which were intended either for his own collection or in order to sell to some of his other patrons, or both.

The principal object represented is the small marble version of a Venus which Strada extends to the viewer [Fig. 12.9]. It is reminiscent of a type traditionally associated with the Aphrodite Pselioumene mentioned by Pliny among the works of Praxiteles, but represents either a probably contemporary variation of that statue or-more likely — a fruit of Titian's fertile imagination. ${ }^{42}$ A small male torso in white marble and a small female draped figure in bronze

\footnotetext{
41 Discussed above, Ch. 8.

42 Panofsky 1969, p. 81, following Klein 1899, pp. 60-62, who duly notes the divergence from the type; cf. Heenes 2010, p. 286, n. 4. Krahn 2008 suggests that the statuette is a version of a lost antique torso, one among the antiquities bought for Duke Albrecht which Strada had restored by Alessandro Vittoria.
} 

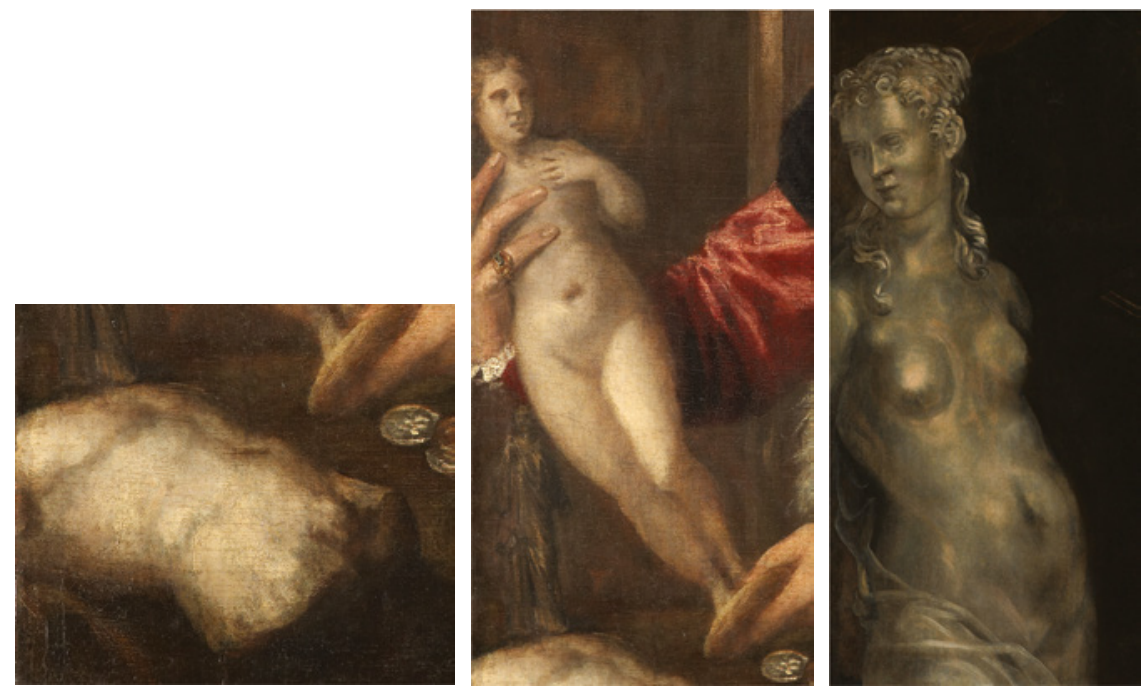

FIGURES 12.8-12.9 Titian, Portrait of Jacopo Strada [Fig. 0.1], details showing the marble statuette of Venus and a male torso.

FIGURE 12.10 Tintoretto, Portrait of Ottavio Strada [Fig. o.2], detail showing the life size Venus in white marble.

are placed on the table[Figs. 12.8 and 12.12] and a slightly larger sized Hercules of the Farnese type in bronze, placed on the shelf above Strada's head, is cut off by the upper edge of the painting [Fig. 12.11]. In Tintoretto's portrait of Ottavio Strada, painted at the same time, the subject is clutching a small fragmentary metal statuette in one hand[Fig. 12.13], while leaning on a life size, nude Goddess — doubtless a Venus — of white marble [Fig. 12.10].

One should beware of trying to identify these exact objects: the odds are that they are figments of the artist's imagination, as is the case with Tintoretto's Venus, which has much more in common with Alessandro Vittoria's style than with that of Greek or Roman sculpture. But they do represent the type of material Strada would have collected in his Musaeum.

The only individual items we know to have been in Strada's collection are the probably small-sized antiques incorporated in a Kunstschrank described in the inventory of paintings and some other works of art that Strada offered at some point in time to Duke Albrecht V of Bavaria, which will be discussed in greater detail below. Principal items were the portrait heads of Philip of Macedon, of his son Alexander the Great and of Hannibal; a female head identified as 'Capuana'; and the heads of two children, 'one laughing, the other crying', all in marble. The cabinet moreover contained a number of other small antiquities: a bust of Faustina in marble, and one of Minerva in 'metal', prob- 

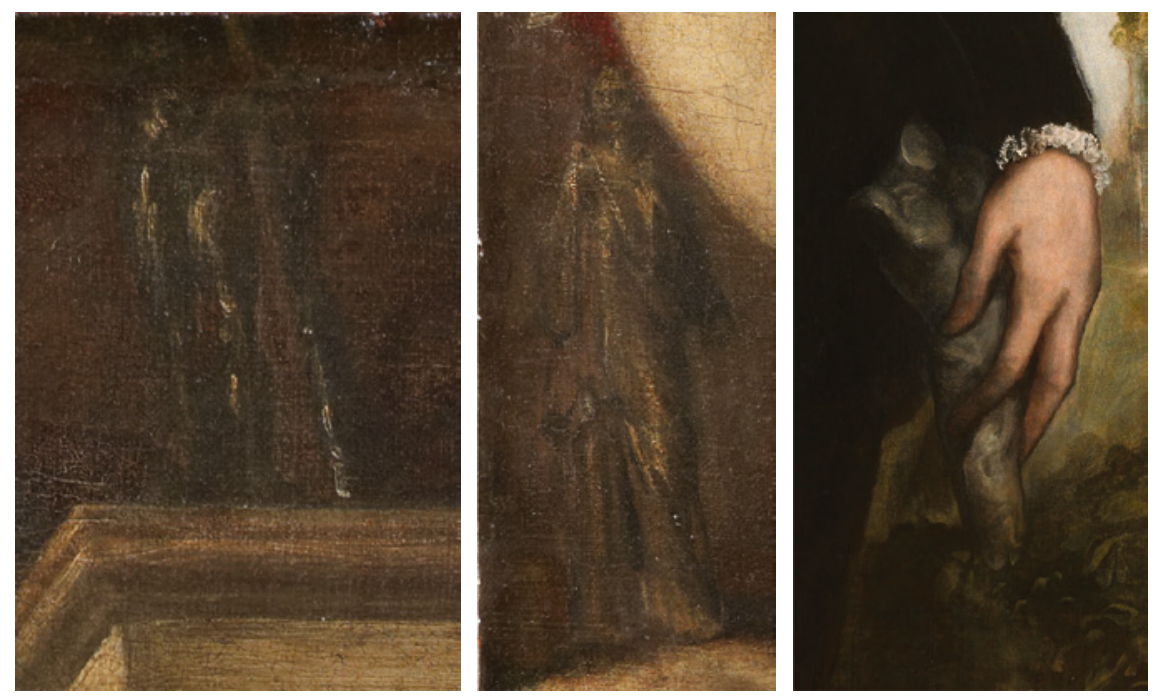

FIGURES 12.11-12.12

Titian, Portrait of Jacopo Strada [Fig. o.1], details showing the bronze statuettes of a Hercules and a draped female figure.

FIGURE 12.13

Tintoretto, Portrait of Ottavio Strada [Fig. o.2], detail showing the fragmentary statuette.

ably bronze, as were the statuettes of Apollo, a male and a female Satyr and two horses. Two 'Piramiden von Marmor' were probably marble obelisks topping the cabinet. ${ }^{43}$ But Strada must have possessed antique sculptures besides these, if his house even included a workshop where antique statuary could be restored. An example of this is found in a letter of the Mantuan envoy about the presentation of an antique sculpture of a Satyr which the Duke had sent as a gift to Maximilian II in 1572 . Unfortunately it had broken in two during transport, and the envoy applied to Strada to have the parts reunited, which was done in too much of a hurry, because it broke again in the same spot while being carried to the Hofburg. ${ }^{44}$

\subsubsection{Casts of Imperial Portrait Busts}

The only other concrete information we have is that Strada owned a collection of busts of Roman emperors and empresses. These, however, were not originals: they were casts which Strada had commissioned after the best exemplars he had seen in various collections, such as those owned by Cesare Gonzaga,

43 Cf. Appendix C, 'Pleasant paintings'.

44 Docs. 1572-05-28; 1572-06-12. 

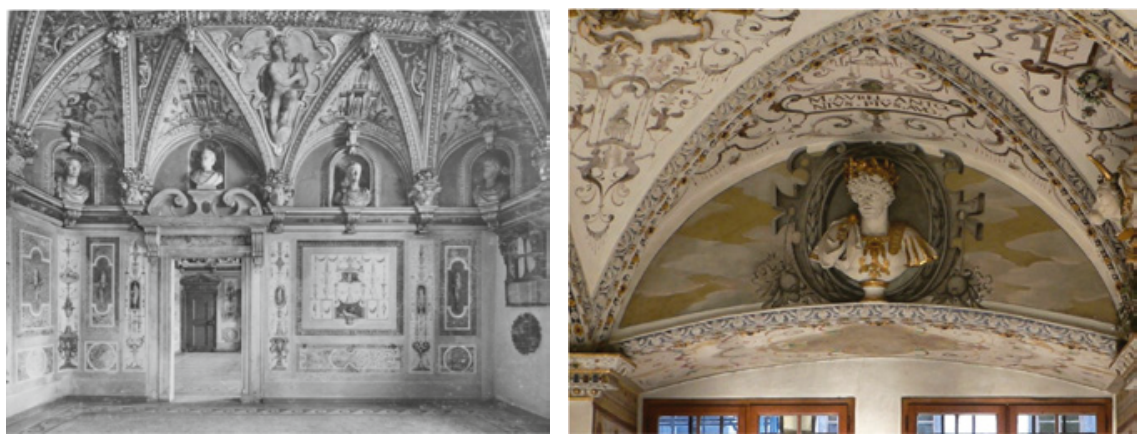

FIGURE 12.14

Friedrich Sustris and Carlo Pallago, Decoration of a room in the Fuggerhaus, Augsburg (1569-1573).

FIGURE 12.15

Bust of Marcus Aurelius, Imperial Chamber, Bučovice castle (ca 1583).

Signore of Guastalla and Duke of Amalfi. ${ }^{45}$ We know from Stopio's correspondence with Hans Jakob Fugger that Strada had these made to be placed 'over the doors and in niches' in his own house, which was 'being built in the Italian manner'. This strongly suggests that Strada planned to decorate one or more rooms of his studio or Musaeum in a manner reminiscent of the room in the Fugger house in Augsburg that was commissioned at about this time by Hans Fugger, Hans Jakob's nephew, and executed after designs by Friedrich Sustris and Carlo Pallago [Fig. 12.14]. A similar use was made of stucco busts in the Imperial Chamber at Bučovice, which can be attributed to Strada, as argued in chapter 10.4, and can be considered as a-probably more sumptuousreflection of his own studiolo [Figs. 12.15 and above, Figs. 10.17-10.20].

Though not originals, in being high quality casts of the best available Roman portrait sculpture, these busts made a strong impression on Strada's guests and served as inspiration for the artists employed in his projects. They were quite well-known and were coveted by several other collectors: thus at one time Hans Jakob Fugger had expressed his wish to acquire them, and in 1574 his nephew Hans Fugger would make an attempt to buy them, in order to have them cast in bronze to fit inside the niches of his splendid new room. By that time Strada was ready to sell them to Duke Albrecht, who earlier had expressed his interest in them, and Strada thought they could well serve to

45 On Cesare Gonzaga (1536-1575) and his exquisite collection of antiquities, described in Vasari/Milanesi, 6, pp. 489-49o, see Brown/Lorenzoni 1984 and Brown/Lorenzoni 1993. 
provide models ('padroni') for the busts still to be made for the portrait heads acquired for the Munich Antiquarium. ${ }^{46}$

It is possible that a set of careful drawings of intact Roman portraits busts preserved among Strada's materials in the Austrian National Library at Vienna documents these gesso sculptures - or rather the originals from which they had been cast [Fig. 12.15 and 12.16-12.17; and below, Figs. 13.74-13.77]. Recent research has revealed that several of them reproduce statues in the collection of Don Cesare Gonzaga at Mantua, which have been preserved in various locations. ${ }^{47}$ It is not clear how large the set of casts was: Strada's elder son Paolo still could offer twenty of them for sale after his father's death. ${ }^{48}$ They provided part of the models for a book containing a series of designs of imperial portraits based on antique sculpture, two manuscript versions of which of are preserved in the Kupferstich-Kabinett in Dresden [Fig. 12.18 and below, Figs. 13.78 and 13.79-13.81]. Ottavio Strada's codex depicting imperial portrait busts presented

46 Stopio to Fugger, 5 October ${ }_{1567}$ (BHStA-LA 4852, fol. 75/69): 'Ho inteso che il Strada ha fatto gettare di gesso alcune teste in Mantua che ha il S[ign]or don Cesare Gonzaga, non so se quelle havera mandato a Vienna, o Monacho'; Stopio used this as an excuse for himself having sent plaster casts instead of the real thing to the Duke, to which Fugger indignantly repplied (23 December 1567, ibid., fol. 111/104): ‘<..> et vi ingannate di larga che'l Strada habbi fatto gettare q[ue]lle cose di Mantua p[e]r l'Imperato[re] o il Duca, anzi l'ha fatto far $\mathrm{p}$ [er] se med[esim] o per adornamento di casa sua $\mathrm{p}$ [er] le porte et nichi di q[ue] lla essendo fabrichata alla italiana<...>'; Strada to Fugger, 1 March 1574 (Doc. 1574-03-01): 'Già Vostra Signoria mi disse che sua Excellenza averia voluntieri auto le mie teste delli Imperadori et Imperatrice di gesso, le quali sonno le più belle che siano in tutto Italia, et le ò fatte formare con grande mia spesa; le quali sarianno buone per padroni per far li busti a quella di marmoro di Sua Excellenza. Se Vostra Signoria ce ne vole dire una parola sta a Lei; Gli darò ancora le pitture et medaglie, et se non vorrà li libri li terrò per me. Anche le dette teste si potranno far ancora gittar di bronzo con il tempo. Mi è stato a trovar un cittadino di Augusta, et quelle teste me ne a dimandato un inventario, con le pitture, et mi disse volerle mandare in Augusta a donare a un gentilhuomo; ma non mi volse dire il nome. O poi saputo sottomane che le voria per il Signor Giovan Fochero, et le voriano far gettar di bronzo per metter in un sala che fa fare molto suntuosissima. Io non ne farò altro insino alla rissolutione di Vostra Signoria, aspetandone però la risposta dala ordata di questa un mese'. Some of the copies were possibly made by the sculptor Giovanni Battista della Porta, who was sent to Cesare Gonzaga with a letter of introduction by Strada in June 1568 (Doc. 1568-06-16).

47 Vienna, ÖNB-HS, Cod.min. 21,3, fols. 61r-7or.; at least five of these busts have been identified among the relics of Cesare Gonzaga's collection now in Turin Racconigi and Casale Monferrato; cf. Riccomini $2014<$ a $>$ and Riccomini 2014<b $>$. Dr. Riccomini kindly informed me that further busts can be identified among the relics of Cesare Gonzaga's collection preserved in Parma.

48 Doc. 1592-03-18: Hugo Blotius to Wolfgang Rumpff, Vienna, 18 March 1592: 'Habet idem Paulus venalia viginta Caesarum antiquorum capita pectoribus ex gypso affabre factis imposita'. 

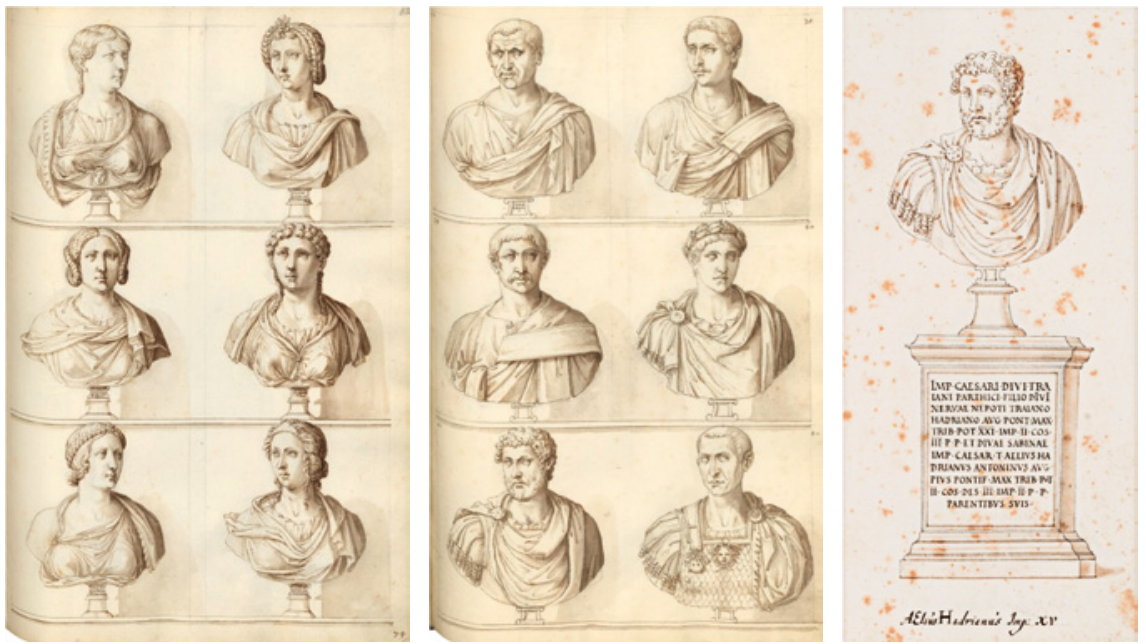

FIGURES 12.16-12.17

Jacopo Strada or workshop, drawings of Roman portrait busts; Vienna, Österreichische Nationalbibliothek.

FIGURE 12.18

Jacopo Strada, Bust of the Emperor Hadrian, a drawing from the manuscript Strada lent to Elector August of Saxony in 1574; Dresden, Kupferstich-Kabinett.

to Grand Duke Ferdinando I of Tuscany in 1600 may well be a copy of the version his father had intended for the press. ${ }^{49}$

\subsubsection{Coins and Medals}

Titian's and Tintoretto's portraits of Jacopo Strada and his son both include antique coins, which constituted a separate section of Jacopo's Musaeum [Figs. 12.19-12.20]. In his brief descriptions Strada generally distinguishes between his medals and his other antiquities. It is natural that, as one of the foremost numismatists of his generation, he would have owned a coin-collection of some note: a collection that was not large, he claims, but of exquisite quality. In the pursuit of his numismatic studies Strada had visited many cabinets of collectors in Italy, Germany and in France, and had carefully documented the best exemplars of individual issues he had seen. This documentation was the

49 Dresden, Kupferstich-Kabinett Ca 74 and Ca .75,76 and 77, see below, Ch. 13.7.1; the version Strada intended to have printed is described in the Index sive catalogus (Appendix D), nr. 6. The Florence manuscript is in Ottavio's hand; it was accompanied by letters of presentation to Ferdinando I of Tuscany and his secretary Belisario Vinta, dated Prague 28 November and 16 December 1600 (ASF, Medici del Principato 90o, f. 218 and 311). Its two volumes are now in the Biblioteca Laurenziana in Florence, Med. Palat. 235a-b. It is illustrated, but not discussed, in Marx 2007, pp. 213-214, figs. 52-53. 

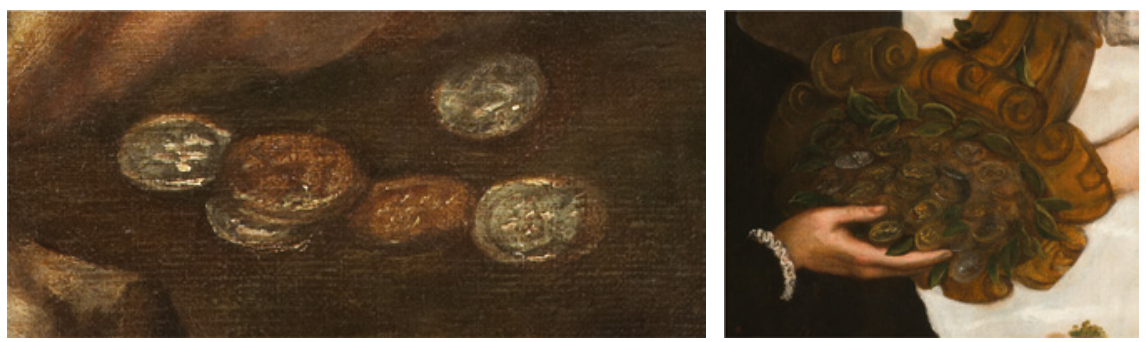

FIGURE 12.19 Titian, Portrait of Jacopo Strada [Fig. 01], detail showing antique coins.

FIGURE 12.20 Tintoretto, Portrait of Ottavio Strada [Fig. 0.2], detail showing a cornucopia showering a profusion of antique coins.

basis for the sets of splendid numismatic drawings he made for Hans Jakob Fugger and his other patrons.

That these were serious studies is borne out by the verbal descriptions with which Strada intended to accompany them, preserved in two bulky sets of manuscript volumes in Vienna and in Prague, the A(ureum) A(rgentum)

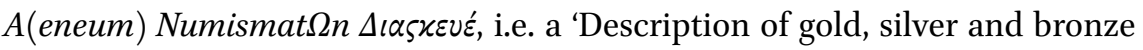
antique coins'. Because in these entries he always mentioned the collection where he had seen the best exemplar, it is possible to reconstruct at least part—and probably the best part—of his own collection, and to compare it with those of some of his contemporaries. From this it results that, at least as to its size, Strada's description of his own coin cabinet is overly modest: except for those possessed by Antonio Agustín, Strada's own medals are most often used as the source for his descriptions. Even taking into account that Strada would have had a bias for his own coins, or that he may have possessed relatively many rare issues of which he had seen no other exemplars, one can conclude that his collection must have consisted of at the very least about two thousand coins, and probably many, many more. ${ }^{50}$

5o $A[$ ureorum $] A[$ rgenteorum $] A[$ ereorum $]$ Numismatwn Antiquorum $\Delta \iota \alpha \sigma x \varepsilon v \varepsilon ́$, Vienna, Universitätsbibliothek, Ms III-160898 (old shelf mark III 483); Prague, University library, ms. VII A 1. It is discussed in Jansen 1993, pp. 215-220; some examples of the descriptions and the breakdown of the provenance of the coins listed in the first five volumes, ibidem, annex 1a, pp. 227-230 and 1b, pp. 231-232. These five volumes (out of eleven) describe a total of 4430 coins, owned by about 50 different collectors: Agustín (942 entries) and Strada (883 entries) each correspond to about a fifth of this total. This does not necessarily imply the other collections were smaller or of lesser quality, but it does imply that Strada had studied these two collections in greater depth. All the same it is clear that Strada possessed a huge collection of coins; so his note in his letter to Jacopo Dani of 1581 'le mie medaglie, le quali, se ben non son molte, sonno però exquisitissime' (Doc. 1581-11o2) probably indicates that by that time he had already sold a large part of them to one or more of his patrons, but had kept the best ones for himself. The $\Delta$ ı $\sigma \varkappa \varepsilon v \varepsilon$ would make it 


\subsection{Acquisitions of Other Materials in Venice}

\subsubsection{Miscellanea}

Apart from the antiques from the Zeno and Bembo collections, a quantity of coins of undefined provenance and his incidental expenses, the final account that Strada presented to Duke Albrecht V of Bavaria mentions a further quantity of miscellaneous, non-antique items that he had provided. ${ }^{51}$ Most of these objects were of relatively minor importance, as can be inferred from their prices, and they are never mentioned in the correspondence. It is possible that Strada had been given carte blanche for acquisitions of this type, but it is more probable that - well aware of the Duke's and Fugger's taste and preferenceshe bought this type of items on his own account: when his patrons had made their choice after his return to Munich, he would not have found it too difficult to dispose of the remainder elsewhere.

Few of these objects are of interest in themselves, but their variety gives an indication of the range of Strada's competence. They included a number of independent works of art, which we would class among the fine, rather than among the decorative arts: four metal statuettes - probably small bronzesrepresenting a Victoria, a Jupiter, an unidentified female figure and a rearing horse, and some paintings of little value: a Hercules and the portraits of 'Pope Julius' and of 'a Greek woman'. Moreover Strada listed an enigmatic item of no less than three hundred and sixty ducats which he had paid to a merchant in Mantua, Guidoto Garotto. This consisted partly of fifty ducats worth of 'other stones' - perhaps pietre dure or rather antique gems or sculpture fragments - and partly of 'several paintings': though unspecified, at three hundred and ten ducats these must have been of some importance, and I will come back to them below. ${ }^{52}$

possible to reconstitute it to a large extent, which would allow a more precise analysis of Strada's collecting habits and his numismatic practice, and compare them to those of his contemporaries.

$5^{1} \quad$ BHStA- $L A 4853$, fols. 11-21. The incidental expenses included restoration, packing, storage and transport of the objects, some clothing for Strada and his son Ottavio, who functioned as his assistant, and even one ducat ' $<\ldots$.. den Saal im Palast und zu St. Marco und das Arsenal zu sehen', i.e. to see (the state rooms of) the Palazzo Ducale, San Marco and the Arsenal (Stockbauer 1874, p. 35).

$52 \quad$ BHStA-LA 4853, fols. 11-21; Stockbauer 1874, p. 33: '1 Gemälde mit einem Hercules v.2'. <...> '1 Bild Victoria' < ...> '1 Bild Jovis' < ...> '1 Frauenbild' < ...> '1 springendes Pferd' (all in metal and together priced at 30 ducats); p. 34.: ' 1 Papst Julii Contrefait v 7 f 3 st 10'. <... ' 1 Gemälde einer griechischen Frau v 5' < <..> 'So habe ich zu Mantua dem Guidoto Garoto, einem Kaufmanne allda, die übrigen Steine bis zu 50 und etliche Gemälde zu bezahlen v 360 '. 
Fine craftsmanship was represented by a silver crucifix, a looking glass in a richly decorated gilt frame and a black marble basin..$^{33}$ Of special interest is a tabletop-which came provided with a finely wrought base-executed in the technique often indicated as commesso di pietre dure, a term that was literally translated into German in the account: ' 1 Tisch mit zusammengesetzten Steinen'.

Apart from these finished specimens of the technique, Strada also bought a quite considerable quantity of semiprecious stones. ${ }^{54}$ These may have been intended merely as raw material for the manufacture of similar objects by the Duke's own artists, but it is also thinkable that at least the larger plaques were meant to be used in interior decoration, in particular of the Munich Antiquarium itself. Such a display of rare and precious sorts of marble, many of which came from Greece and Asia Minor, had been realized in those rooms of his palace at Santa Maria Formosa in Venice where Giovanni Grimani, Patriarch of Aquileia, housed his collection of antiquities. This was very famous at the time and well known both to Stopio and to Strada himself. ${ }^{55}$ [Fig. 12.21] Finally part of the stones may have been acquired for the Duke's Kunstkammer by virtue of their mineralogical interest, such as the fossilized piece of wood and the thirtyfour balls ('Kugeln') of 'all sorts of rare and oriental stones'. ${ }^{56}$

Certainly intended for the Kunstkammer were the various items of archaeological, historical or ethnological interest that Strada provided: in the first place the numerous ancient coins and medals, including those from the Loredan collection, but also two cameos or intaglios, either antique or at least 'all'

53 BHStA-LA 4853, fols. 11-21; Stockbauer 1874, p. 33: '1 silbernes Crucifix v 30. <...> 1 runde länglichte Schale von schwartzen Stein sammt 2 anderen Steinen v 30 f 4 st 10'; p. 34: ‘ Spiegel mit vergoldeten Angesichtern v 6'.

54 BHStA-LA 4853, fols. 11-21; Stockbauer 1874, p. 33: '1 Tisch mit zusammengesetzten Steinen und feinem ausgearbeiteten Fuss v. 80'; the pieces of semiprecious stones listed pp. 33-34. BHStA-LA 4852, fol. 150; Stopio to Fugger, 22 February 1568: 'Io haveva invitato il Strada $<\ldots>$ ma l'ha mandato ad scusare, che ha tanto da fare tutto il dì con il patriarca che a pena ha tempo da mangiare $<\ldots$. '. Stopio also knew the Palazzo Grimani and its collections, and sent a design of its 'tribuna' to Munich, cf. above, Ch. 8; on the Palazzo Grimani, see Perry 1981; Tafuri 1985, pp. 15-17 and figs. 7-10; Bristot 2008. The palace and its restoration were the subject of a colloquium, Il Palazzo e le collezioni Grimani a S. Maria Formosa, Venice, 4-5 October 1985; on its marble decorations a communication was made by L. Lazzarini, 'I marmi di Palazzo Grimani'. It is now a museum.

$5^{6}$ Strada also ordered stone slabs for the inscriptions for (the bases of) the statues, as reported in his letter from Mantua to Duke Albrecht: 'De li tavole di paragone ne ordinaro a la suma di cento, computando le prime, le quali in mia absenza si metranno a la fine, e lassaro buon ordine che si mandaranno'. (Doc. 1567-07-12); they cannot be the stones mentioned in Strada's account, for these were all coloured, whereas 'pietra di paragone' is a black marble. 


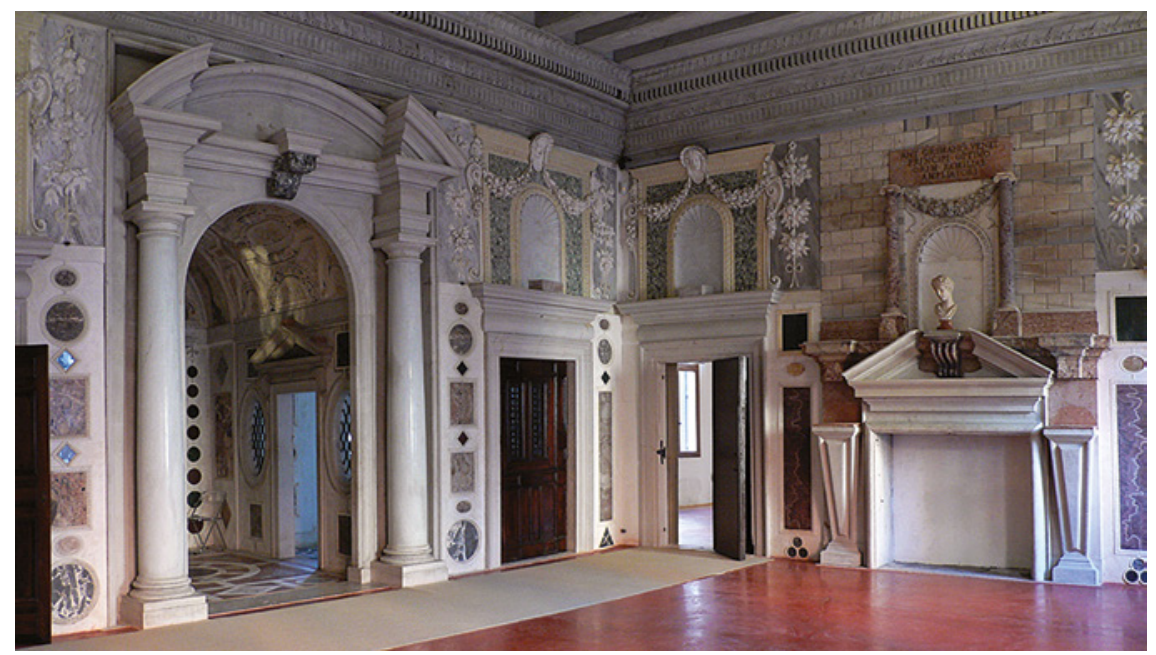

FIGURE 12.21

The use of plaques of rare marbles in the decoration of the Palazzo Grimani at Santa Maria Formosa, realized around the time of Strada's visits to Venice.

antica' and also the painted portraits of 'Pope Julius' and the 'Greek woman'; a damascened inkwell, and finally a 'wooden' book written in Egyptian hieroglyphics. A large quantity of Hebrew and Arabic books, probably manuscripts, shows that Strada did not forget the Duke's library. ${ }^{57}$

\subsubsection{Strada's Acquisitions of Paintings}

Strada had bought the 'etliche Gemälde' included in his account to the Duke (and which were therefore certainly acquired on his behalf) from a certain Guidoto Garotto, a merchant resident in Mantua, about whom nothing further is known. The status of this acquisition is unclear: though three hundred sixty ducats is no paltry sum, apparently the paintings were not highly considered by Strada, if he does not list them individually, like most of the other objects acquired. Or perhaps their purchase was considered as a separate deal, which was only added to his account at the last moment for purely administrative reasons. ${ }^{58}$

57 BHStA-LA 4853, fols. 16-20; Stockbauer 1874, pp. 34-35.

$5^{8}$ Garotto cannot have been very important, as his name (Garoto, Garottto, Caroto, Carotto etc.) does not occur in Rebecchini's survey of private collections in Mantua in the sixteenth century (Rebecchini 2002), nor in Venturini's publication of the voluminous correspondence between Mantua and the Imperial court (Venturini 2002). 
In addition to this purchase there are other concrete indications that Strada was at least occasionally involved in the trade in paintings. According to Stopio in May 1567, soon after his arrival in Venice, Strada acquired a quantity of fiftythree paintings, which — Stopio claimed - had earlier been offered to himself for thirty ducats less than Strada had paid for them. Later in the year Strada bought on two separate occasions, but perhaps from the same source, a total of thirty-eight paintings 'di quelli quadri tutti moderni', though having earlier rejected two similar ones from this same collection that Stopio had shown him as a teaser. The provenance of these paintings remains mysterious: because of the large quantity it is unlikely that Strada bought them directly from the artists involved. They may have been purchased from a Venetian collector, but it is more probable that they were supplied by a professional dealer: possibly again by Guidotto Garotto in Mantua, but more likely by someone in Venice. That Strada bought these paintings after having disparaged them to Stopio may have been be due to his wish to oust competition and acquire them on the cheap, as Stopio had it, but it may just as well have been because their general quality was higher than the two that Stopio had first shown him. ${ }^{59}$

It is not clear which patron Strada had in mind when making this purchase, for which he held no commission from Munich. There is no evidence either that they were intended for the Emperor, though that certainly cannot be excluded. It seems rather unlikely that Strada would have bought such a large quantity of paintings - ninety-one items! —all at once merely for his own collection. Yet the possibility cannot be excluded, as Strada himself fourteen years later ranked his paintings with his antiquities, speaking of his 'studio delle antiquità et pitture excellentissime'. ${ }^{60}$ But it is most likely that he bought them partly on speculation, hoping to sell them off one by one to various patrons.

59 Stopio to Fugger, 9 May 1567 (BHStA-LA 4852, fol. 15): 'Io non so se'l compra per Sua Eccellenza, ma lui ha comprato fin a 53 de quelli quadri tutti moderni, li quali mi sono stati prima offerti per più di 30 scudi mancho di quelli lui le ha hauti<... >'; id., 10 October 1567 (ibid, fol. 77): 'Il Strada come scrissi ha pure comprato anc(or)a lui in 2 volte 38 de q(ue)lli quadri moderni; non so se li haveria mandato a S. Ecc.<...>'; id., 12 October 1567 (ibid., fol. $74):$ ‘ $\ldots>$ non so anche se havera mandato costí li 38 quadri ch'l comprò modernissimi, li quali dispregiò nel principio quando io le ne mostrai dua, et essendoli poi dimandato da uno al quale lui disse che ne haveva veduta in man mia et dispregiati, perche lui le havera poi comprato, li rispose che le dispregio a me, perche vedendo ch'io dissi che s'offerrano a bon merchato, le voleva comprare lui<... >';. BHStA- $L A$ 4852, fols. 77, 103-107.

6o Strada to Jacopo Dani, Vienna, 2 November 1581 (Doc 1581-11-02). 


\subsubsection{Contacts with Living Artists in Venice}

Though Strada appears to have bought the batches of paintings discussed above from one or more merchants, it is perfectly possible, even likely, that he also acquired works of art directly from their makers. Strada's contacts with the artists living in Venice were very extensive, and they are much better documented than his contacts with the local dealers. In June 1567 Stopio reported to Fugger that 'il Strada non prattica qui con scultori, se non con orefici e desegnatori di stampe in rame, o miniatori, che è il suo mestiere'. ${ }^{61}$ Strada was acquainted with many of these artists since his earlier visits to Venice: with the goldsmiths because they were to some extent his colleagues, and also because their shops were the natural repositories of the smaller anticaglie, such as coins and medals, cameos and intaglios, and small bronzes. ${ }^{62}$ His interest in the book trade and in any type of material visually documenting a great variety of subjects brought him into contact with the miniaturists and the engravers; and he would employ the latter to execute the illustrations for his edition of the Settimo Libro of Sebastiano Serlio's architectural treatise, though the book itself eventually was printed in Frankfurt. ${ }^{63}$

In asserting Strada's lack of contacts with Venice's sculptors Stopio deliberately deluded Fugger, because he hoped to induce Fugger to employ a sculptor of his acquaintance to execute the necessary restorations of the Duke's newly acquired antiquities. But he almost immediately contradicted himself when he related to Fugger how Strada had declined an invitation to lunch with him because he already had an appointment with Alessandro Vittoria that day. Strada commissioned Vittoria to restore some of the Duke's antiques, but he also ordered an independent sculpture, representing Cupid, for which he paid seventy-five ducats. When this arrived in Vienna he appears to have shown it to the Emperor and communicated his high opinion of Vittoria's qualities, for about a year later, when Maximilian began planning the Neugebäude, he asked Veit von Dornberg, his envoy in Venice, for further information about the sculptor. ${ }^{64}$

\footnotetext{
$61 \quad$ BHStA-LA $485^{2}$, fols. $35^{-3} 3$

$62 \quad$ BHStA-LA 4852 , fol. 157

63 On Strada's activities as a publisher, see Ch. 14; Jansen 1989; Jansen 2004.

64 BHStA-LA 4852, fol. 42, Stopio to Fugger, 3 August 1567: 'Circa il suo Cupido, quando che sarà finito, sapera bene il tutto, et ne darò aviso a Vostra Signoria'; ibid., fol. 49: Stopio to Fugger, 1o August 1567: 'mi maraviglia molto che non le habbia inviati inanti, ma penso che vorà aspettare il Cupido che si fa'; ibid., fol. 6o: Stopio to Fugger, 24 August 1567: 'Il Cupido sara finito fra 15 dì, et sara conza la donna, alla quale ha fatto metter una testa et un brazo $<\ldots$.. Io volevo che quella matina fusse venuto meco a desinare il Strada, ma mi disse hiersera suo figliuolo $<\ldots>$ che'l va a desinare con Alessandro Vittorio scultore che
} 
Though no mention is made in Stopio's correspondence of Strada's contacts with Jacopo Tintoretto, these are testified by the portrait which this master made of Ottavio, Strada's second son. Ottavio shared the interests of his father, and had accompanied him to Venice as his assistant, as part of his professional training. The portrait, which is now in the Rijksmuseum at Amsterdam, shows the eighteen-year old Ottavio in the fashionable attitude of a young, melancholic virtuoso of noble birth. It was obviously intended as a pendant for Titian's more famous portrait of his father [Figs. 0.1 and 12.22 and 0.2 and 12.24]. ${ }^{65}$ Strada's connection with the Robusti family is attested moreover by the statement in Raffaele Borghini's Il Riposo of 1584 that Jacopo's talented daughter Marietta had also painted a portrait of Jacopo Strada, which, together with her own self-portrait, had been acquired by Maximilian II. As 'rare things' the Emperor kept both of these in his own chamber, and he made every effort to have Marietta come to his court. ${ }^{66}$
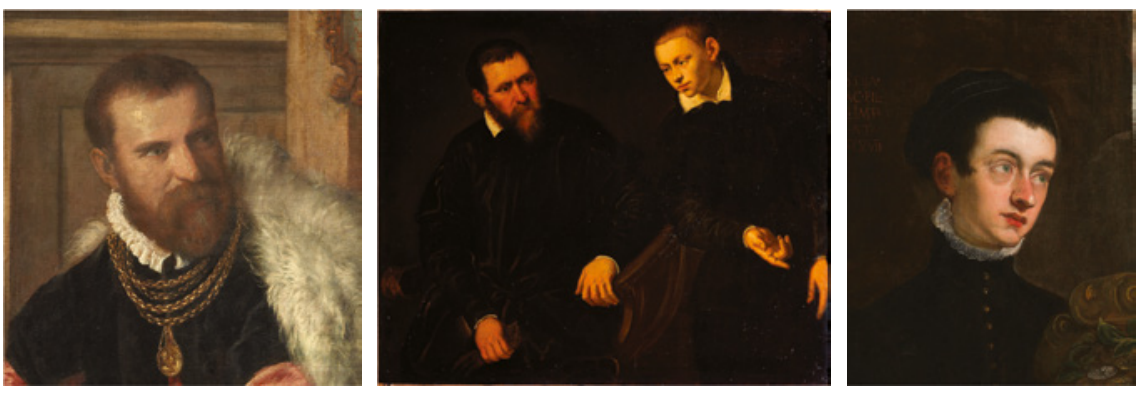

FIGURES $12.22-12.24$

The painting recently attributed to Marietta Tintoretto, as Portrait of Jacopo Strada and self-portrait, dressed as a boy (Dresden, Gemäldegalerie, centre), compared to Titian's portrait of Jacopo (Vienna, left) and Tintoretto's portrait of Ottavio Strada (Amsterdam, right).

fa le queste sue cose<...>'; ibid., fol. 66: Stopio to Fugger, 9 September 1567, speaking of a Paris in Parian marble that Stopio wished to acquire on behalf of Duke Albrecht: 'un amico che ha veduto il Cupido del Strada che li costa scudi 75, dice che questo Paris vale per il dopio, si come è anche più grande di un bon palmo che non è quel suo Cupido' (and the Paris was as large as 'un putto de 7 o 9 anni'). The restoration of the female statue is mentioned in Strada's account (BHStA-LA 4852, fols. 16-20; Stockbauer 1874, p. 32). Maximilian's request for information (Linz 18 December 1568) printed in JdKS 13, Reg. 8807, and discussed in Lietzmann 1987, pp. 163; Podewils 1992, pp. 47-48.

65 Amsterdam, Rijksmuseum, inv. nr. SK-A-3902; cf. most recently Duncan Bull's entry in the catalogue of the Louvre exhibition Titien, Tintoret, Véronèse: Rivalités à Venise (Bull $2009<\mathrm{a}>)$. The dimensions of the painting $(1,28 \times 1,01 \mathrm{~m}$.) are quite close to Titian's portrait of Jacopo Strada $(1,25 \times 0,95 \mathrm{~m}$.).

66 Borghini 1584, p. 558: '[Marietta Tintoretta] dipigne benissimo, et ha fatto molte bell'opere, e fra l'altre il ritratto di Iacopo Strada Antiquario dell'Imperador Massimiliano secondo, et 
Duncan Bull has recently argued the hypothesis that a double portrait now in Dresden, but with a Prague provenance, is the portrait acquired by Maximilian, in which the young servant or pupil would not be the young Ottavio-who would be the wrong age and whose portrait by Marietta's father shows little resemblance-but the self-portrait of Marietta, who was reputed to dress as a boy and go everywhere with her adoring father. ${ }^{67}$ [Fig. 12.23] This identification remains a hypothesis, but the fact that these portraits were painted does suggest a conscious effort at self-advertisement of Tintoretto and his daughter: sending a prospective patron-Maximilian II-splendid portraits of people he knew personally - the Stradas - would convince him of the quality of their authors-Jacopo and Marietta Tintoretto - and might tempt him to place commissions with them. There can be little doubt that it was Strada who served as the channel through which both Marietta's works and her reputation as a girl-prodigy reached Maximilian II.

Strada's relationship with Titian is better documented and certainly it has been more often discussed. Strada's portrait is first mentioned in Stopio's correspondence in February 1568, when he wrote to Fugger:

Titiano and he [= Strada] are like two gluttons eating from the same dish: Strada has him paint his portrait, but he will still work at it for at least a year, and if by that time Strada doesn't render him the services he wishes, he will never finish it. ${ }^{68}$

Apart from a fur-lined mantle-similar to the one Strada himself is wearing in the portrait?-Titian's wishes probably included Strada's intervention on his behalf, with the aim of enabling him to sell paintings from his studio to such exalted and prestigious patrons as the Emperor and the Duke of Bavaria. And in fact Strada did recommend a number of Titian's favole, mythological scenes that were at least in part variations of earlier inventions executed for the Emperor's cousin, Philip II of Spain, as being of sufficient importance to be acquired for the Imperial collections. Strada also exerted his influence at the

il ritratto di lei stessa, i quali, come cosa rara, sua Maestà gli tenne in camera sua, e fece ogni opera di havere appresso di se questa donna excellente, la quale fu ancora mandata à chiedere al padre da Re Filippo e dall'arciduca Ferdinando'.

67 Bull $2009<\mathrm{b}>$.

68 LA 4852, fol. 153-154: 'Titiano e lui [= Strada] son doi giotti a un tagliero: Strada li fa fare il suo ritratto, ma vi stara sopra ben ancora un anno, et se in questo mezzo il Strada non li fara li servicii che desidera, non l'havera mai compito'. 
Bavarian court, as is indicated by the fact that an identical copy of the list sent to Vienna is found among the Munich correspondence. ${ }^{69}$

Titian appears to have had rather sanguine expectations from Duke Albrecht $\mathrm{v}$ of Bavaria: later in the same year he had Strada convey two paintings, intended as gifts for the Duke and for Fugger, to their destinations. ${ }^{70}$ It was not unusual for Titian thus to donate examples of his work as a bait to secure some important commission, or in lieu of payment for services rendered. ${ }^{71}$ It seems likely that the painting he thus presented to Duke Albrecht is identical with the Venus and Cupid with Bacchus and Ceres in the Bavarian State Collections, which is already mentioned in the 1598 inventory of the Munich Kunstkammer. The 'Donna Persiana' he intended for Fugger may well be the presumed portrait of Roxelane, La Sultana Rossa, in the Ringling Museum in Sarasota [Fig. $12.26] .{ }^{72}$

69 The list sent to Vienna is published in JdKS 13, 1892, II. Teil, p. XLVII, Regest nr. 8804; apart from some spelling variants, it is identical to the list sent to Munich (BHStA-LA 4853, fol. 31). Maximilian responded with a request for further information, fearing that Titian's ages had impaired his eyesight (ibid., p. XLVIII, Regest $\mathrm{nr}$. 8806).

$70 \quad$ BHStA-LA 4852, fol. 110, Stopio to Fugger, 12 December 1567: 'Messer Titiano manda salutare a Vostra Signoria, et ancora lui spera domane havere riposta alle sue, et m'ha detto di havere alcune pitture in ordine per mandare poi a Vostra Signoria, et al Signor Duca'; BHStA- $L A 485^{2}$, fol. 153, Stopio to Fugger, 19 February 1568; BHStA-LA 4852, fol. 169, Stopio to Fugger, 14 November 1568; BHStA-LA 4852, fol. 209, Stopio to Fugger, 29 January 1569: 'Essendo Vostra Signoria in Viena, sara buona che la vede il ritratto del Strada che ha fatto Signor Titiano, et anche una Dea Pomona, che è una bellissima donna, ritratta con varij frutti; et le vengono presentati; et Vostra Signoria ha da sapere che Signor Titiano, sopra le parole del Strada, che li haveva promesso cose grande, haveva parechiato tre quadri: uno per il signor Duca, una per Vostra Signoria, et una per il Strada, accompagnandoli con lettere a Vostra Signoria; ma il bello è che quando il Strada vidde quello che era stato designato per Vostra Signoria, cioè quella Dea Pomona, disse lui di voler quello per lui, et che'l desse l'altro a Vostra Signoria, che è una Donna Persiana, che penso Vostra Signoria havera hauto; impero vedendo quella Pomona, conoscera se il Strada ha tolto il più bello per se. Il bon Titiano per contentarlo fece a suo modo, et stracciò quella lettera et ne scrisse un altra; hora si duole che non ha haute aviso alcuno da nissuno, ne sa se li quadri siano stati presentati a suo nome o non; imperò mi ha pregato di scrivere a Vostra Signoria di volerne dare qualche aviso'.

71 It should be noted that a 'present' made to a Prince — here Albrecht V—-was generally expected to be compensated by a favour which would be more or less equivalent in value: it offered him an occasion to display the royal virtues of liberality and magnanimity.

72 Diemer/Diemer/Sauerländer 2008, 3, nr. 3208, pp. 986-987; Munich, Bayerische Staatliche Gemäldesammlungen, inv. nr. 484 (not on show); this painting, now attributed to Titian's workshop, is one of several variants of the Allegory of Marriage in the Louvre. In addition to its provenance from the Wittelsbach collections, the bigger size and greater monumentality of this painting suggests that this was the painting intended for, and delivered to Duke Albrecht, whereas Fugger and Strada would have been given images perhaps equally splendid, but more modest in size and of simpler composition (below, note 74). 
Titian quite often used this means to induce his more influential friends to assist him selling his works or to foster his interests in other ways: 'Messer Titian', wrote Giovanni della Casa in 1544 to Cardinal Alessandro Farnese, 'has given me a portrait of our Sovereign Lord [= Pope Paul III] by his own hand, and thus corrupted me to such an extent that its suits me to become his solicitor', whereupon he begged the Cardinal to grant Titian a much desired benefice. It is common knowledge that Titian's relationship with Pietro Aretino was partly based on a similar exchange of goods and services. ${ }^{73}$ Strada was quite fortunate in this respect: apart from painting his portrait, Titian presented him with another painting by his hand, or at least from his studio: a 'Dea Pomona, chè una bellissima donna ritratta con vari frutti', probably the Lavinia holding a bowl of fruit now in Berlin [Fig. 12.25]. ${ }^{74}$
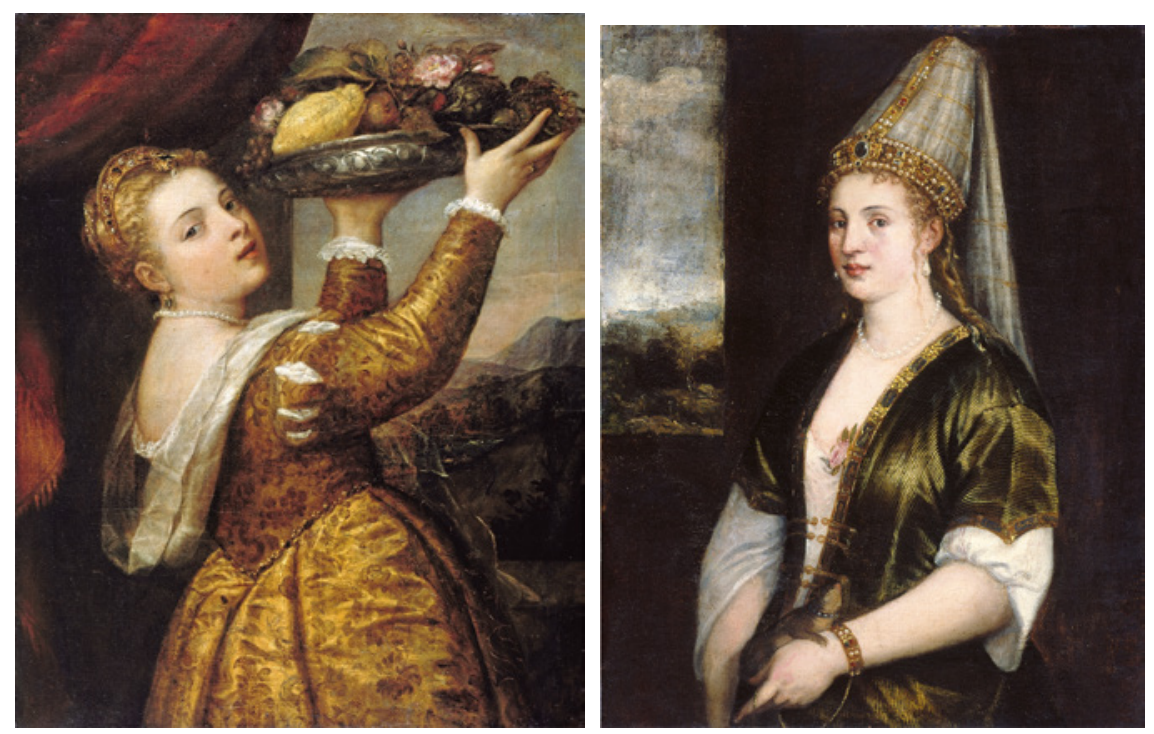

FIGURE 12.25

Titian, Lavinia holding a bowl of fruit: probably the 'Dea Pomona' Titian gave to Jacopo Strada; Berlin, Staatliche Museen.

FIgURE 12.26 Titian, La Sultana Rossa, ca. 1550-156o; perhaps the Persian woman Titian gave to Hans Jakob Fugger? Sarasota, The John and Mabel Ringling Museum of Art.

73 Quoted in Hope 1977, p. 189: 'Messer Titian mi ha donato un ritratto di nostro Signore di sua mano, et corrottomi di maniera, che mi convien essere suo procuratore'.

74 Stopio (cited above, note 70) claimed that Titian had prepared three paintings, one for Duke Albrecht, of which he does not mention the subject, and one each for Fugger and for Strada; he claims that Titian originally intended a 'Dea Pomona' for Fugger, 'ch'è una bellissima donna ritratta con varij frutti che le vengono presentati', and a 'Donna Persiana' for Strada, but that Strada, himself preferring the 'Pomona', had him change their intended recipients. Diemer/Diemer/Sauerländer 2008, 3, nr. 3208, pp. 986-987, connect the 'Dea Pomona' mentioned by Stopio with the Munich Venus and Cupid, but this seems 
This indicates that Titian did expect quite solid benefits from Strada's exertions on his behalf. Stopio asserted that Titian had been taken in by Strada's persuasive eloquence, implying that he had never derived any concrete advantage in return for the favours he had done him. ${ }^{75}$ It is difficult to determine to what extent Titian's expectations were realized, but it is rather likely that Stopio's estimate is too negative: there is, for instance, no reason not to suppose that Maximilian II did acquire at least some of the favole he had been offered around this time. ${ }^{76}$ Finally, several paintings by Titian are included in an undated list of paintings Strada offered to the Bavarian court, which will be discussed in greater detail below. Some of these were described as 'old', and were probably bought from collectors or dealers, but most of the others must have been bought directly from the painter: the 'four portraits made by the widely renowned [painter] Titian's own hand' are the most likely candidates. ${ }^{77}$ It is after all unlikely that, in addition to Strada's portrait, Titian would have donated three major paintings without any immediate benefit; it is even quite possible that Strada had actually bought the favole he recommended to Maximilian II

unlikely: it stands to reason that Duke Albrecht would have received the more monumental of the three paintings, and the continued presence of the Venus and Cupid in the Wittelsbach collections since 1598 strongly suggest that this is in fact the painting Titian sent to the Duke. It is not surprising that Stopio's description confused the bowl of fruit carried by the Pomona and the basket of fruit and flowers offered to Venus in the larger painting, since it was over a year ago that he had seen the three paintings (if he had seen them at all). The reason for the exchange may have been quite different from that given by Stopio: perhaps Strada preferred a portrait of Titian's daughter Lavinia because he himself had a daughter of that name? As usual, Stopio's representation of the facts would be strongly biased against Strada: in his correspondence with Fugger he left nothing unsaid which could harm his rival with their common patron. Fugger saw through this, and shortly afterwards took Stopio sternly to task for this slander (BHStA-LA 4852, fols. $228 \mathrm{ff.}$., Fugger to Stopio, Vienna, 30 March 1569; cf. above, Ch. 12.3.1).

75 BHStA- $L A 4852$, fol. 230, Stopio to Fugger, 9 April 1569, responding to Fugger's letter of 30 March cited above (note 18) '<...>a proposito del Strada, che Signor Titiano disse che era un venerabile presuntuoso, et ignorante, più tosto che intelligente, ma che cacciava tante carrotte con questo suo simulato procedere alli Alemanni quanto si può imaginare; li rispose alhora quel amico che di ciò non si maravegliava, ma bene di questo, che esso Signor Titiano, tanto accorto, se l'haveva così lasciato cacciare, di farli un ritratto et donare ancora una pittura in un quadro, che a qualunque suo amico non haveria fatto per $5^{0}$ scudi<...>'

76 This is almost certainly the case for the Diana and Callisto in the Kunsthistorisches $\mathrm{Mu}$ seum in Vienna (inv. nr. GG-71; Wethey 1969-1975, III, pp. 142-143).

77 Appendix C: '4 retrati vom weitberuembten Tiziano aigner hand gemacht' (only three are specified); cf. below, Ch. 12.6 . 
and Albrecht $\mathrm{V}$ on his own account, taking the responsibility for and the risk involved in their further sale on his own shoulders.

Unfortunately there is only one other transaction involving both Strada and Titian that is securely documented. This had nothing to do with any of Titian's own works, but instead concerned a small but very valuable casket in rock crystal set in a silver gilt mount and decorated with precious stones. This casket belonged to Carlo della Serpa, who had been First Chamberlain to Pope Julius III. Della Serpa, who wished to sell it together with a variety of other precious objects in his possession, had given the casket to Titian in security for a loan that the artist - 'la stessa avaritia et diffidentia', according to Stopio—had made him. Titian showed it to Strada, who thought it might be a suitable present for Prince Wilhelm of Bavaria, Albrecht's son and heir, to give to his bride. Through Strada's mediation Titian finally did succeed in selling the casket to the Duke, placating its owner, who had hardly been consulted, by arguing that this transaction would open up opportunities to dispose advantageously also of his other 'galanterie..$^{78}$ In this way Titian was enabled to demonstrate his goodwill towards the Duke and doubtless also to make a considerable profit on the transaction: so at least on this occasion Strada's interference was to his immediate advantage. Strada himself will likewise have gained financially from the deal; yet it must be kept in mind that-just as in the acquisition of the Loredan collection — he did not act as a merchant — who would have bought the casket on his own account, to sell it at a possibly large profit—but merely as an agent for Albrecht v. ${ }^{79}$

78 On this transaction, see BHStA-LA 4851, fols. 325-326; 348-349; and BHStA-LA 4852, fols. $56,83,91,97-98,100-102,111-112 ; 119 ; 131$ and 142. Among the other objects owned by Della Serpa was found 'la sua tavola', possibly identical with the table top in pietre dure mentioned in Strada's account (BHStA-LA 4853, fol. 16-20; Stockbauer 1874, p. 33). The casket does not figure in the inventory of the Munich Schatzkammer, but it may perhaps have looked somewhat like the beautiful casket consisting of rock-crystal panels by Annibale Fontana depicting biblical scenes bought by Duke Albrecht for 6.000 scudi (Brunner 1970,

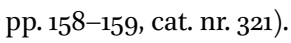

79 Whatever Stopio in his envy of Strada may have insinuated, Titian must have had good reasons for painting Strada's portrait and presenting him with the Pomona. Apart from whatever services in profitable transactions he expected Strada to perform, he may well have appreciated the acuteness, energy and enthusiasm that he caught so well in his portrait. Moreover, in view of Strada's affluence at the time, it remains perfectly possible that he actually paid for them. 


\section{Commissions in Mantua}

\subsubsection{Paintings}

When visiting Venice, Strada habitually also spent some weeks in his native town, Mantua. Apart from acquiring some antiques there, and having casts made of some busts from the collection of Cesare Gonzaga, Signore of Guastalla, which he intended to use in the decoration of his own house in Vienna, he employed various young artists to execute copies of works of art in the Duke of Mantua's collection, and to prepare detailed documentation of some of the chief artistic monuments of that town. In this again he apparently acted on commission from Fugger; if not, his patron was at least well aware of these activities, the results of which he was eager to acquire for the Duke's Kunstkammer. This is clear from the letter in which Fugger asked Stopio to gather detailed information on Strada's affairs in Mantua, and in particular about the prices he paid for the various items he commissioned. Stopio was eager to oblige, and his reply, enclosing a report sent him by some acquaintance in Mantua, well supplements the evidence of Strada's own letters. ${ }^{80}$

From these sources it appears that Strada employed a local painter, called il Molinarolo, to paint copies of a number of paintings kept in the Duke of Mantua's own apartment in the Palazzo Ducale or found elsewhere in Mantua. These included a 'Dea della Natura' - presumably the 'Madre Natura' by Giulio Romano that in 1627 was hung in the Camerino delle Muse-and two paintings

$80 \quad$ BHStA-LA 4852: Fugger to Stopio, 6 December 1567 (fols. 97-101); Stopio's reply, 23 January 1568 (fol. 126) enclosed a report (fol. 130) by his informer in Mantua, an otherwise unknown person called Il Cerragagno (fol. 138): 'Strada è stato qui, et ha fatto far uno modello del Palazzo del T. dal architetto del Signor Cesare Gonzaga, et poi l'ha fatto anco dissegnar in foglij da un giovane qui nostro amico; il qual gli ha appresso dissegnato tutte le camere et sale di detto palazzo, et di più fa anco dissegnar da questo giovane le stanze del Castello dove sta il Signor Duca nostro; et fa ritrar in avolio duodeci Imperatori con le historie, che sono in una camera in Castello; fa anco rittrar due Venere, una in piedi, et l'altro distesa, et di più ha detto che vuol far dissegnar molte altre belle cose che sono qui. Quel giovane che dissegna si chiama Messer Hippolito de Andriasi, et gli dà poi, quanto ho inteso, dui scudi d'oro la settimana, et egli si è obbligato a dargli tanti foglij di dissegno la settimana. Quel altro che fa quei ritratti si chiama il Molinarolo, et gli da per quanto ho anco inteso quindeci scudi d'oro del pezzo'. Strada seems to have maintained regular contacts with Cesare Gonzaga, Lord of Guastalla and of Amalfi, a noted collector and connoisseur of antiquities; cf. Brown/Lorenzoni 1984. In 1568 Strada recommended a sculptor, Giovanni Battista della Porta, to Cesare Gonzaga (Doc. 1568-06-16), probably also in order to have him execute copies and/or casts from items in Cesare's collection, among which (part of) the busts Strada acquired for the decoration of his own house discussed above (Ch. 12.4.2); on the documentary drawings of Cesare Gonzaga's 'studiolo', a sumptuous cabinet for collectibles, see below, Ch. 12.7.4. 
by Correggio, the School of Love (now in the National Gallery in London, and the Venus, Cupid and Satyr (now in the Louvre), that at the time were still in the collection of Count Federico Maffei [Figs. 12.27 and 12.28]. ${ }^{81}$

Most important, however, were the copies of a number of paintings from the Camerino dei Cesari. Here Strada had copied for the Duke not the famous portraits of the eleven first Roman Emperors painted by Titian, as has been assumed, but instead the scenes from their lives, one 'Historia' for each, that Giulio Romano and his assistants had painted to go under the portraits themselves [Figs. 12.29-12.30]; and likewise the smaller paintings, depicting the
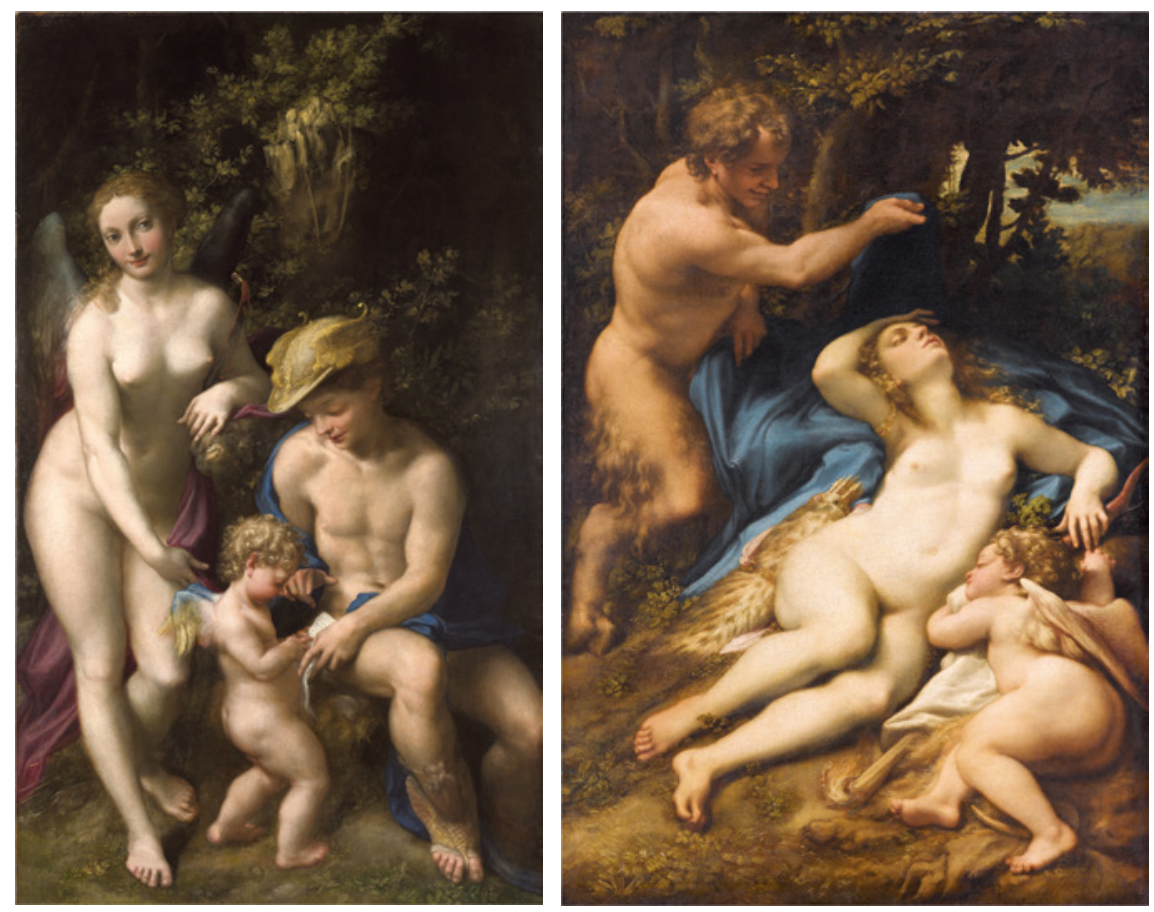

FIGURES 12.27-12.28 Antonio del Correggio, The School of Love (London, National Gallery) and Venus, Cupid and Satyr (Paris, Musée du Louvre).

81 Cf. the letter of 'Il Cerragagno, Stopio's Mantuan informer and Strada's autograph note 'Pitture che fo fare imitare', included in BHStA-LA 4852, fol. 176 and printed in Verheyen 1967 , p. 64, n.31. Giulio's 'Dea della natura' is mentioned in the 1627 inventory of the Gonzaga collections (Luzio 1913/1974, p. 115). Guido Rebecchini has discovered that the Correggio paintings are listed in a 1589 inventory of the collection of Count Federico Maffei, who had died in 1586 (Rebecchini 1997, pp. 274-275); this implies that they had not been commissioned by Isabella d'Este or her son Duke Federico, as has generally been assumed; cf. Verheyen 1967, p. 64; Gould 1976, pp. 213-216 and 238-239. 
Roman soldiers on horseback, that filled the spaces between the Historie [Figs. 12.31-12.32]. ${ }^{82}$ Finally Strada had also copied the portrait of the twelfth Emperor, Domitian, which Titian himself had never painted for lack of space, but with which Bernardino Campi had completed the series shortly before, when he prepared his first set of copies, commissioned in 1562 by the Marquis of Pescara. The Duke of Bavaria apparently already possessed copies of Titian's originals of the other eleven, since a complete series of twelve is still preserved in the Munich Residenz: apart from the Domitian, these are probably identical with the set painted by Campi for the Emperor Ferdinand I: they may have come to Munich as a gift on some festive occasion, or as part of Duchess Anna's inheritance. ${ }^{83}$
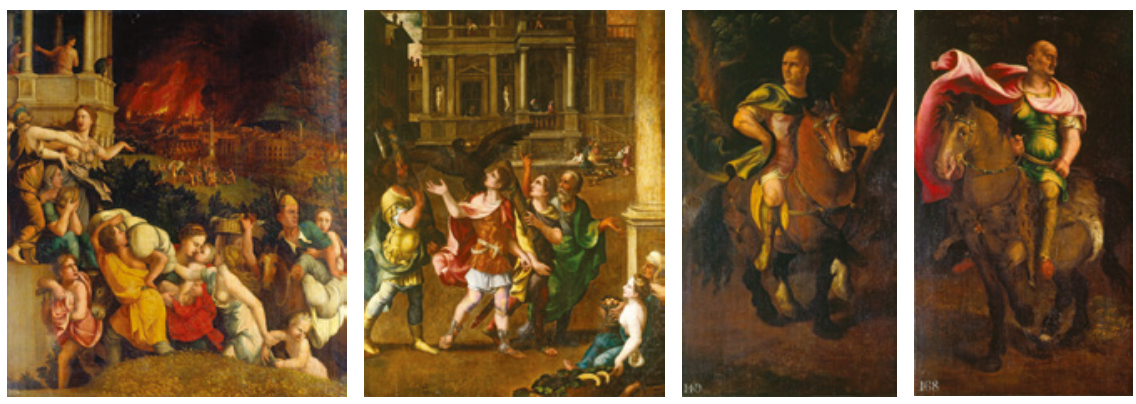

FIGURES 12.29-12.32

(Workshop of) Giulio Romano, paintings from the Camerino dei Cesari in the Palazzo Ducale in Mantua: the scenes Nero playing the fiddle while Rome is burning and The Omen of Claudius; two Roman warriors on horseback; all Hampton Court, British Royal Collections.

82 Stopio's Mantuan informer and Strada's autograph note 'Pitture che fo fare imitare' (as in the preceding notes). On the Camerino dei Cesari, see Verheyen 1967, n. 31; Verheyen 1966, pp. 170-172, pl. 40-42; Wethey 1969-1975, III, pp. 43-27 and 235-240; Splendours of the Gonzaga 1981, pp. 190-192; Harprath 1984, pp. 18-19; Giulio Romano 1989, pp. 400-405, and below.

83 On the many sets of copies after Titian's Mantuan Emperors, see Wethey 1969-1975, III, pp. 235-240; figs. 31-50. The Munich copies were later integrated as dessus-de-porte in the eighteenth-century boiseries of the so-called Reichen Zimmer of the Munich Residenz. Strada did in fact have copies made of the Titian Emperors' portraits themselves, but not for Duke Albrecht (who already owned Campi's series), for they are not mentioned in Strada's account. They were probably intended for his own studio; as noted above (note 5), he presented them in 1575 to the Elector August of Saxony: 'die ersten zwelf Römische kha[i]ser vom Julio Cesare bis auf den Domitianum, von elfarben gemalt, durch den besten maler, der heindtichs tag im Welzlandt ist'. [Doc 1575-09-28; printed in Lietzmann 1997, p. 396-397]. 
At first sight it seems therefore that Albrecht V intended to recreate in some way the entire Camerino dei Cesari within the walls of his own residence. This is not quite as surprising as it may seem: the Bavarian branch of the Wittelsbach had already much earlier demonstrated their interest in the artistic achievements of their Gonzaga relatives. As discussed in chapter 2.3, after a visit to Mantua in 1536 Albrecht's uncle, Duke Ludwig X, had had built his town palace in Landshut after designs by Giulio Romano, by artists and craftsmen from Mantua specially engaged for the purpose. Albrecht knew this complex very well, since he resided at Landshut until his accession to the Duchy in $155^{\circ}$. That his own interest in Mantua's secular architecture extended beyond the Camerino dei Cesari-which after all might have appealed to him merely for its iconography and the great name of the principal artist involved-is demonstrated by his acquiring the additional documentary material that Strada brought from Mantua. Among these was a model of the Palazzo del Te Strada had commissioned from 'the architect of Don Cesare Gonzaga', probably Francesco Capriani da Volterra. ${ }^{84}$

\subsubsection{Documentary Drawings}

Moreover Strada commissioned the young Mantuan painter Ippolito Andreasi to prepare detailed measured drawings of the exterior as well as of the interior decoration of all the principal rooms of the Palazzo del Te and of some of the rooms in the Palazzo Ducale, among which the Camerino dei Cesari and the Sala di Troia. The model has been lost, but the drawings ended up in the print room of the Düsseldorf Kunstmuseum, where they were first signalled by Egon Verheyen in 1966. In 1984 Richard Harprath correctly identified their draughtsman, and included them in his catalogue raisonné of Andreasi's drawings. They were quite extensively used in the research preparing the ground-breaking exhibition on Giulio Romano in the Palazzo del Te in 1987. A selection of them was shown there in conjunction with the room by room description of the Palazzo del Te with which Strada had complemented the set of drawings, thus deliberately constituting a body of documentation that remains of considerable importance for a good understanding of the monument. ${ }^{85}$

84 The material mentioned in Strada's final account, BHStA-LA 4853, fols. 11-21, printed in Stockbauer 1874, p. $32-36$, the drawings p. 34.

85 On these drawings, see Verheyen 1967 and Verheyen 1977, passim; they are catalogued in Harprath 1984, pp. 3-28 and in part illustrated, plates 4-13. Strada's description of the Palazzo del Te is in Vienna, ONB-HS, Cod. 9039, fols. 57-58; its text published in Verheyen 1967, pp. 68-69. Both description and drawings are included and discussed in Amedeo Belluzzi's monumental monograph on the Palazzo del Te (Belluzzi 1998, Saggi, pp. 30-36 and passim). 
Linking these drawings with the plan for the construction of the Munich Antiquarium that at the time were being developed, Verheyen suggests that Duke Albrecht intended to have a more or less exact replica built of the Palazzo del $\mathrm{Te}$, pointing out that otherwise there would have been no need to have noted the measurements so precisely in the drawings. ${ }^{86}$ Such an assumption may have been plausible in the case of the Camerino dei Cesari: after all here copies of all its constituent parts-except for the ceiling fresco-were in the Duke's possession, and to realize a replica of this one room would have required little further expense and even less space. It is also true that Strada himself shortly afterwards suggested that the octagonal ceiling panels from the Sala di Psiche in the Palazzo del Te should be copied, so as to incorporate these copies within the ceiling of the large rectangular room or hall above the Antiquarium that was to house Albrecht's library. But because of the completely different proportions of the two spaces, it is clear in this case that a strict imitation of the Sala di Psiche was never intended. ${ }^{87}$ And whatever the intended destination of the copies after the paintings in the Camerino dei Cesari, these ended up an integral part of a numerous collection of portraits of rulers and prelates housed in a quite large room of the Munich Kunstkammer. ${ }^{88}$ If the reconstruction of such a small room as the Camerino dei Cesari was deemed impracticable, it can safely be excluded that the idea of imitating a complete palace or even only part of it ever crossed the mind of Albrecht $V$ or his advisers. The credit for the precision of the drawings, and the inclusion of its exact measurements, should rather be given to Strada's perfectionism and to his intention to have them published one day; this interest ties this commission immediately to his own collection of graphic documentation, which will be discussed in greater detail below. As splendid objects providing detailed information on a monument of international renown, they fitted seamlessly into the concept of the complex of collections being realized at Munich, the raison d'être of which had been so carefully set out in Samuel Quiccheberg's treatise on collecting published two years earlier: no further justification for their acquisition by Duke Albrecht is necessary.

86 Verheyen 1967 , pp. 64-66.

$87 \quad$ BHStA-LA 4853, fols. 27 and 6o; Von Busch 1973, pp. 127-128.

88 As described in Johan Baptist Fickler's inventory dating from 1598, publishd in Diemer 2004 and exhaustively commented in Diemer/Diemer/Sauerländer 2008, 2, nrs 2599, 2617, 2625, 2631, 2638, 2645, 2652, 2659, 2666, 2675, 2682 (portraits), 26oo, 2610, 2618, 2626, 2632, 2639, 2646, 2653, 266o, 2667, 2676, 2683 (scenes); comment on pp. 749-753, and in the separate article by Dorothea Diemer, 'Mantua in Bayern? Eine Planungsepisode der Münchner Kunstkammer', ibidem, 3, pp. 320-329; they had been earlier discussed in Hartig 1933a, pp. 207-211 and Jansen 1987, pp. 14-15. 


\section{7 'Gemalte Lustigen Tiecher’: Contemporary Painting in Strada's Musaeum}

The antiquities and the visual documentation, such as the drawings of the Palazzo del Te, to be admired in Strada's house mostly appealed to the more learned among his visitors. Less sophisticated visitors of the Musaeum may have been more impressed by the display of contemporary works of art it offered, be it permanently as a fixed private collection, be it in continuous exchange as the stock of a high-class art dealer.

Some of the works presented had a particular significance for Strada and his family or were highly esteemed for other reasons. The former category included the two portraits of himself and his son Ottavio painted by Titian and Tintoretto [Figs. 0.1 and o.2], the latter probably included the Dea Pomona Titian had presented to him as personal gift [Fig. 12.25]. ${ }^{89}$ These will have been more or less permanent fixtures, not for sale, whereas other works, though acquired both for their quality and particular appeal, would have been available to patrons if they made a serious offer. This is a situation which is not so different from that of many art-dealers of today, where the distinction between private collecting and buying to sell is not always very clearly defined. Thus the set of copies in oils of Titian's portraits of the first twelve Roman Emperors must have been intended to decorate a specific space in Strada's house, perhaps the very studiolo where Strada practiced his researches into their history and (numismatic) iconography. Nevertheless, he did not hesitate to offer them to the Elector August of Saxony when this served his purpose. Probably most of the other paintings in Strada's studio would be available to a patron making a serious offer. Stopio gives no indication about the ninety-one paintings Strada bought in Venice in 1567 , except that they were all 'modern'. Fortunately another document preserved in Munich allows a more detailed impression of the character of Strada's collection of paintings.

\subsection{1 'Pleasant Painted Canvases' Offered to Strada's Patrons: The Document}

In view of Strada's documented patronage relationship with three of the best and best-known artists active in Venice at the time- the sculptor Alessandro

89 The Pomona was a gift is documented in Stopio's correspondence, cf. above, Ch. 12.5.3. It has often been interpreted as a portrait of Titian's daughter Lavinia. This may have been an additional reason for Strada to exchange it with the painting of 'a Persian lady' originally intended for him, for his youngest daughter also was called Lavinia or Lavina. It is not certain which of the versions of this composition was the one given to Strada. 
Vittoria and the painters Tintoretto and Titian-it is very unlikely that he would not also have had some contact with the third member of Venice painterly triumvirate, Paolo Veronese.

Though a direct connection between Strada and Veronese is not documented, a list of works of art that Strada at some point in time offered to the Bavarian court included a set of two huge allegories with an Imperial theme attributed to that master. Their inscriptions, mentioned in the text, allow the identification of these two paintings with Veronese's Wisdom and Strength and The Choice between Virtue and Vice, both now in the Frick Collection in New York, which suggests that these two paintings may have been commissioned by Strada, either for himself, or on behalf of some more exalted patron [Figs. 12.33 and 12.34]. ${ }^{90}$

To date this list, preserved in the Munich Libri Antiquitatum, has been chiefly discussed by scholars studying Veronese's two Frick allegories. ${ }^{91}$ It is not in Strada's hand, but since it appears to be written in the hand of a secretary also
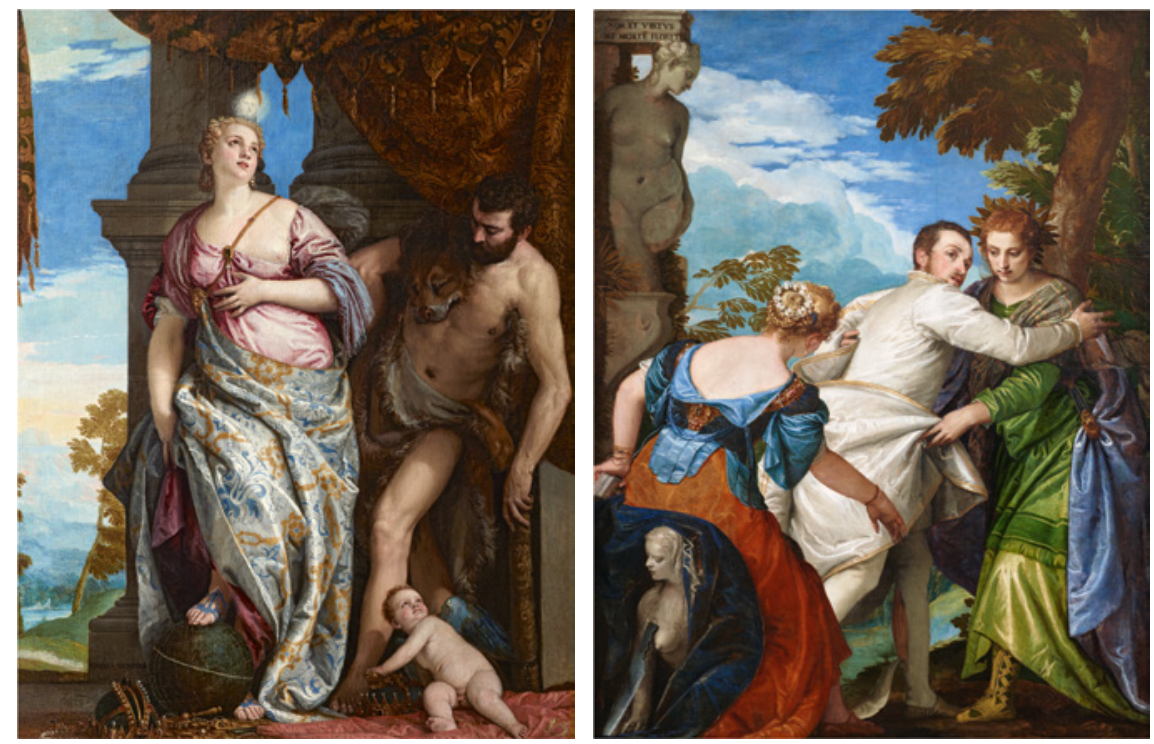

FIGURES 12.33-12.34

Paolo Veronese, Wisdom and Strength and The Choice between Virtue and Vice; New York, Frick Collection.

9o I am very grateful to Duncan Bull to have drawn my attention to this and to have provided me with the relevant documentation, as well as made me profit from his expertise in the field. Bull has treated the issue in his recent catalogue entry of the Titian portrait (Bull 2009a, pp. 211-213).

91 Conveniently summarized in Salomon 2006, pp. 20-24; in particular notes 85-89. 
responsible for other Strada documents and is filed among the documents relating to Strada's acquisitions in Venice and Mantua in $1567-1569$, it has been generally related to these, and dated to this period. But this is not an inevitable conclusion: the Libri Antiquitatum were put together only at a later date, and the file was meant to include all material relating to Strada's dealings with the Munich court. This context therefore does not contradict the arguments that can be proposed to date the document somewhat later. A brief discussion of its contents and its probable function will help to understand the context of Strada's role as a collector and/or a purveyor of works of art produced by his contemporaries.

The list, in German, is headed 'Pleasant painted canvases from the hand of skilful painters in Venice and elsewhere in Italy, all in oils' [Figs. 12.35-12.36]; a transcription is given in Appendix C.92 The many Italian terms in the text ('ditto', 'quadro', 'retrati') indicate that the German text was derived from an Italian source, was dictated, translated or edited by a German who himself was used to think in Italian — or the other way round. Perhaps this was Strada himself, more likely it was Paolo or Ottavio Strada. It is not clear what its function may have been: since it gives no estimates or prices, it cannot have been part of a formal offer of sale to Fugger or the Duke, much less an account of objects actually delivered in Munich. The rather general tenor of the heading and of the descriptions of the individual items suggest that it was drafted in order to interest various patrons in the collection, rather than that it was specifically addressed to Duke Albrecht and Hans Jakob Fugger, the latter of whom would not have needed a version in German and certainly would not need to be told that
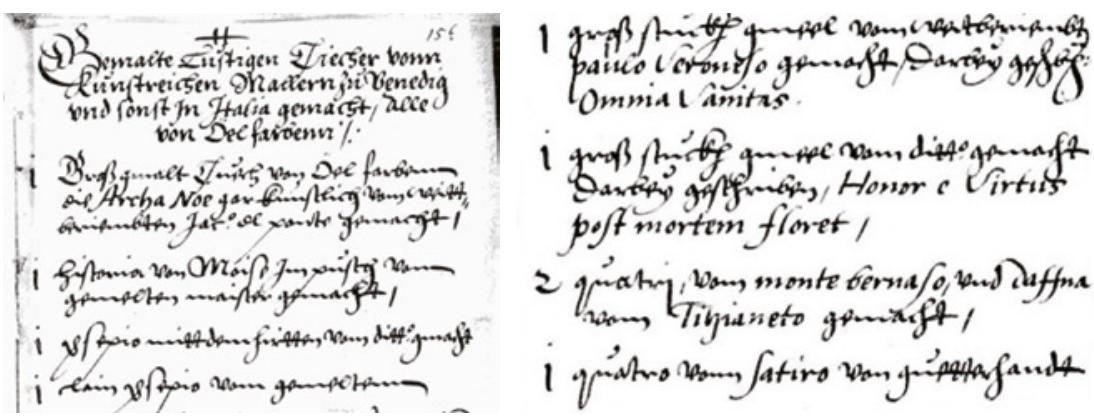

FIGURES 12.35-12.36

Heading and a detail of the list of 'Lustigen Tiecher' which Strada sent to Munich, probably in the early or mid-1570s. Venedig und sonst in Italia gemacht, alle von Oel Farbenn'. It was printed in Stockbauer 1864, pp. 43-44, for a more precise transcription, see Appendix C. 
masters such as Titian and Veronese were 'weitberuembt', 'widely renowned'. Its presence in Munich does, however, indicate that Strada did hope that he might interest his Bavarian patrons in the acquisition of the entire collection or of some of its individual components.

The list gives no indication at all of the provenance of the collection or of the individual works. Since Strada could offer it to the Duke, it was either a collection in his own possession or a collection to which he had privileged access. It lists forty-two paintings, mostly full-sized canvases, but also a few smaller items, and then continues with a not inconsiderable quantity of other materials, including some fat volumes of drawings and prints, some illustrated books, some coins and medals, some sculpture - mostly small bronzes—and some miscellaneous Kunstkammer items. What is perhaps the most fascinating object in the list, a 'Kunstschrank' or cabinet of inlaid wood filled or decorated with antique marbles, allows to link the list more definitely to Strada. Its contents included two small antique marble heads of ' 2 khinder eins lacht / das andre waintt'. This relates the list to the earlier inventory of the Bussoni collection, which included 'Capita duorum puerorum unus eorum qui ridet et alter qui ploret': 'the heads of two children, one of whom laughs, the other cries'. As we have seen above, that inventory, dated March 1562, is in Latin and commented in German; it is likewise preserved in Munich and can be associated with Strada. The later presence of these sculptures in such a monumental cabinet - which would have taken some considerable time to have designed and made - is an argument that the document may be later in date than has been assumed on the basis of its presence among documents relating to Strada's acquisitions for Duke Albrecht mostly dating from 1568-1570. An additional argument for a later dating is the adjective 'weitberuembt' or 'widely famous, applied to the painter Niccolò Frangipane, one of Titian's lesser pupils known to have been active only from 1563 onward. This suggests a date at the earliest in the early or mid-1570s.

Most of the material included in the list - the antiquities, the coins and medals, the volumes of prints and drawings and the books on architecture and fortification-corresponds closely to what we know from other sources to have been in Strada's collection. In his recent catalogue entry on the portraits of Jacopo and Ottavio Strada Duncan Bull has accepted Klara Garas' andfollowing Garas-Xavier Salomon's suggestion that the list is in fact an inventory of (part of) Strada's own collection doubling as dealer's stock.' ${ }^{93}$ This is indeed a most plausible explanation: the Munich list is one of several copies of

93 Garas 1990, p. 18; Campenhausen 2003, pp. 12 and 16-21; Salomon 2006, p. 22; Bull 2009a, p. 212. 
a survey Strada edited once he began, in the mid-1570s, to try and sell his house and collections in order to finance his publishing projects. So the list represents a choice of those objects Strada could miss, and which he thought might most appeal to his prospective patrons. He would have circulated it among his patrons, hoping that one of them might be interested in acquiring the collection as a whole, but ready to name a price for any individual object they might fancy. ${ }^{94}$

This implies that paintings mentioned in this document are not necessarily identical with those in either of the two separate collections of contemporary paintings Strada is reported by Stopio of having bought in the summer of 1567 . Doubtless some of the paintings acquired on those occasions are included, but we cannot be certain even of that: Strada may have acquired paintings on other occasions and in other locations Stopio knew nothing about, and there is no reason to suppose that he stopped buying pictures after he left Venice, or that he had never done so earlier. Yet since most of the paintings listed here are by Venetian artists, such as Giorgione, Titian and his son or nephew, Veronese, Bassano, Tintoretto and Frangipane, or by artists active in Venice, such as Salviati, it is likely that in fact Strada bought or even commissioned most of them during his visits to the Serenissima.

\subsubsection{The Frick Allegories: A Strada Commission?}

That these paintings cannot be demonstrated all to have been part of Strada's wholesale acquisitions in the summer of 1567 removes an obstacle to Duncan Bull's hypothesis that the two Veronese allegories in the Frick collection were in fact commissioned by Strada directly from the artist. It is in any case rather implausible that such monumental paintings would have been made without a specific patron in mind. Bull suggests that they were made to complement the portraits of Jacopo himself by Titian, now in Vienna, and of his son Ottavio by Tintoretto, now in Amsterdam. Wisdom and Strength would then serve as an allegorical pendant to Titian's portrait of the father, and The Choice between Virtue and Vice to Tintoretto's portrait of the son. ${ }^{95}$ If so, the project was not

94 The earliest instance of this is his offer of both house and collections to Vilém z Rožmberk in the autumn of 1573. (Doc. 1573-12-18); his attempts discussed below, Ch.14,6. As argued above, the reference to the Kunstschrank and to Frangipane as a famous painter suggests a date for the list in the 1570s; the date does not need to correspond to the other documents in the relative volume of the Libri Antiquitatum, because Strada remained in contact with Duke Albrecht and Hans Jakob Fugger long after having concluded his acquisitions for the Antiquarium, and it is plausible that the Munich archivists, when putting the Libri Antiquitatum together, included material Strada sent later in this same file.

Bull 2009a, pp. 211-213. 
thought out in detail beforehand to fit into one of the rooms of Strada's new house, since in that case the compositions, the backgrounds and the lighting would probably have been coordinated more carefully.

Moreover the two allegories, though of the same size, are painted on a different type of canvas, which suggests that they were not commissioned simultaneously. Yet that does not exclude a connection with the two portraits, which most likely were also commissioned consecutively: once the first allegory had turned out well and Strada had persuaded Tintoretto to paint a portrait of Ottavio, he may have asked Veronese for a second allegory to accompany it, which would neatly explain the difference in canvas used for the two allegories. Whether intended as an ensemble or not, the presence of these four paintings in Strada's house must have made quite an impression in Vienna, and it is likely that this was what Strada intended. Possibly he merely wished to underline his prestige as a cultured intellectual and noble courtier, but it seems more likely that he also hoped to stimulate his patrons to emulate his example, and to buy or commission similar works of art—preferably through his mediation — with the artists themselves or with collectors and dealers in Venice.

In this Strada or his heirs must ultimately have been successful, because the two Veronese allegories and two other similar allegories by the same master eventually ended up in the collection of the Emperor Rudolf II. ${ }^{96}$ The hypothesis that they were actually commissioned by Rudolf II is contradicted by Strada's offering them to Duke Albrecht in the late 156os or, if my hypothesis of the intention and date of the document is correct, in the mid-1570s at the latest. This should, however, not mean that the allegories may not have been originally intended for Rudolf II. Duncan Bull links the themes of the two allegories to the persons of the two Strada's, showing how it underlined the relationship between the father and the son and potential successor. But such a connection might just as easily be postulated in regard to Maximilian II and his eldest son and heir. The complicated iconography of Wenzel Jamnitzer's Schöner Brunnen indicates that such allegorical references would have been understood at the Imperial court. It seems perfectly possible that Strada commissioned these paintings hoping that he could persuade Maximilian, or perhaps his consort, the Empress Maria, to acquire them, for instance as a gift for their son on the occasion of his coronation as King of Hungary (1572) or as King of Bohemia (1575). The education of Hercules is a perfectly fitting theme to remind a young prince of the duties and responsibilities of his position. The presence at the

96 They are included in the inventory of Rudolf II's collection of 1621, together with the Mars and Venus United by Love (New York, Metropolitan Museum) and Hermes, Herse and Aglauro (Cambridge, Fitzwilliam Museum), cf. Zimmermann 1905, p. XLV. 
feet of the personification of Wisdom of what is quite obviously an Imperial crown only strengthens this supposition. ${ }^{97}$ Though unlikely, it cannot be completely excluded that the paintings were commissioned - through Strada's mediation - by Maximilian II himself, perhaps for the Neugebäude, but were somehow left on Strada's hands. ${ }^{98}$

\subsubsection{An Impression of the Cabinet of Paintings}

In addition to the two Veronese allegories the inventory mentions forty paintings. These were mostly full-sized canvases, but there were also a few described as ' 4 claine retrati' (four small portraits) or ' 1 clain Taffellin' ('one small panel'), as well as a number of other miscellaneous objects. Like those in Strada's acquisitions mentioned by Stopio, the paintings in this list are 'modernissimi' ('quite new'), recent works of major artists working in Venice, except for two paintings by Giorgione and (the young?) Titian, which are explicitly described as 'old'. Unfortunately the descriptions are too summary to identify the paintings mentioned with existing individual works with any certainty. But since artist, technique and subject matter are always indicated in the list, it is possible to illustrate it by means of images of corresponding pictures that are still in existence. It should be noted that - with the exception of two Veronese allegories now in the Frick Collection - as yet none of these paintings can with certainty be identified as the actual objects in Strada's possession. Popular themes were often repeated by their author, replicas and variant versions of various sizes were prepared in his own workshop; very popular ones were copied by other painters. So the paintings illustrated here are not intended to present a hypothetical reconstruction of Strada's collection of paintings, but merely aim to provide an approximation of its size, its character and its quality, and so to help visualize the impact it had on his patrons, his fellow artists and his other guests. ${ }^{99}$

The first paintings mentioned, and therefore probably highly esteemed, are five paintings by Jacopo da Ponte, called Bassano. Three of these are huge

97 This possibility has been suggested by Salomon 2006, p. 20.

98 The list may even date from after Maximilian's sudden death in the autumn of 1576: in that case perhaps Strada was asked to try and sell them in order to meet some of the Emperor's staggering debts. This would explain why nothing is said about the provenance of the paintings. It is quite probable that Strada, as the resident expert at court, would have made such an inventory.

99 Since most painters often provided variant readings of the same subject matter, and even produced several versions of the same pictorial invention, a concrete reconstruction is impossible; detailed investigation of the provenances of potential candidates might make it possible to identify a few of these with objects mentioned in the list. 
scenes from the Old Testament, stories of Noah-perhaps a version of The Animals entering the Ark in the Prado [Fig. 12.37]—and of Moses—perhaps The Israelites drinking the miraculous waters, likewise in the Prado, though of somewhat smaller size [Fig. 12.38]. The two others are a larger and a smaller version of the Adoration of the Shepherds.

The next items, probably also highly regarded, are Jacopo Tintoretto's $\mathrm{Su}$ sanna and the Elders, probably the one now in the Kunsthistorisches Museum in Vienna [Fig. 12.39] and a Venus and Adonis by Salviati (probably Giuseppe Porta, rather than his teacher Francesco Salviati). The latter is complemented by a smaller 'Quadro' (a panel?) of Venus and Cupid of the same master's hand. As we have seen, the reported inscriptions of the following two paintings by Paolo Veronese allow us to identify them with certainty with Veronese's two huge and splendid allegories, The Choice between Virtue and Vice and Wisdom and Strength, that have always remained together [Figs. 12.33 and 12.34].

All these paintings were of large size, they were all indicated as 'grosses Tuch' ('large canvas'), 'grosses Stück' ('large piece') or 'grosses Quadro' ('large painting'- here, in contrast to 'Tuch', possibly indicating a panel?). Most of the following items lack that appellation, and were probably of middling size, except for the few cabinet pieces which were described as 'kleine Ritratti' (small portraits) or 'klein Tafelein' (small panel). They include a number of works by Titian or perhaps from his workshop: two history pieces representing Mount Parnassus and Apollo and Daphne, which are difficult to identify, since this specific theme is not found in Titian's existing oeuvre, and a number of probably half-length human figures ('ritratti'), representing a Turkish prince, a St Sebastian holding arrows - perhaps a painting similar to the small head now attributed to Giorgione in Vienna? [Fig. 12.42] —and a personification of Vanitas, the latter perhaps to be related to the female figures with mirrors in Paris and in Munich [Fig. 12.40].
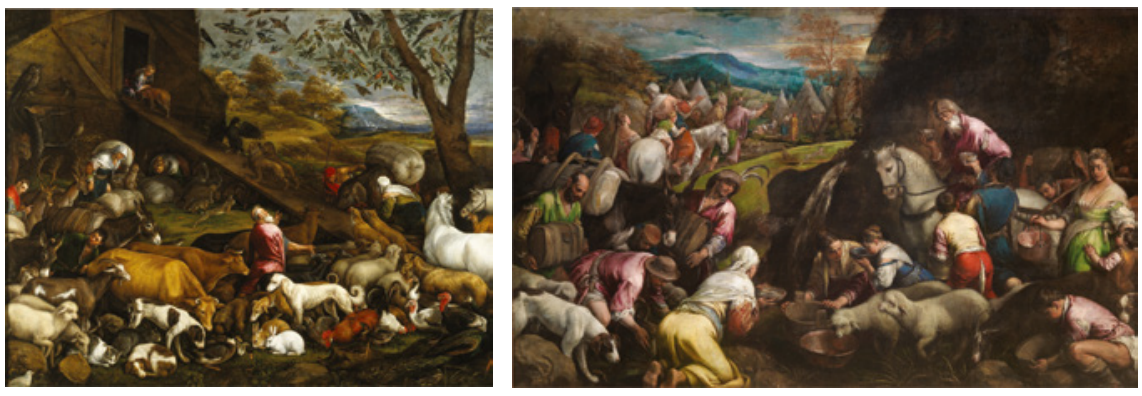

FIGURES $12.37-12.38$

Jacopo da Ponte (Bassano): The animals entering Noah's Ark and The Israelites drinking the miraculous water; both Madrid, Museo del Prado. 


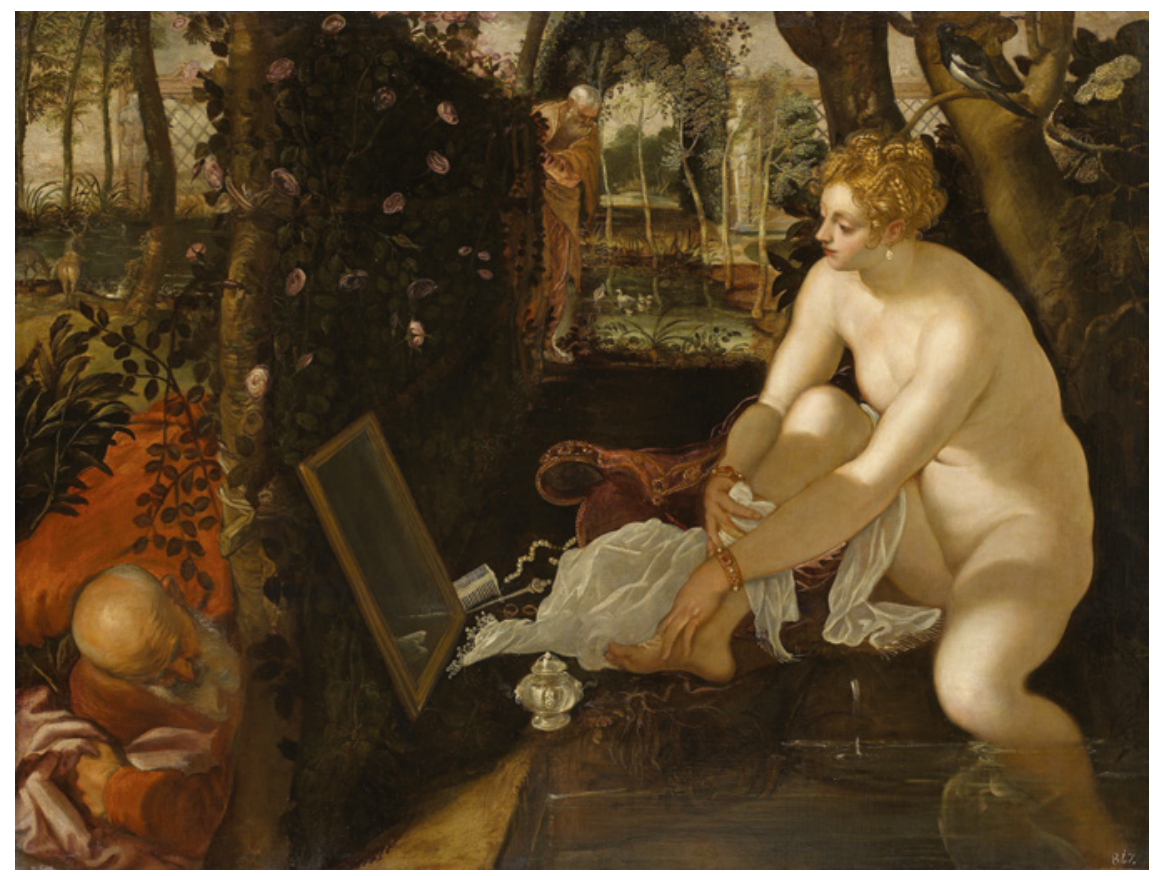

FIGURE 12.39 Jacopo Tintoretto, Susanna and the Elders; Vienna, Kunsthistorisches Museum.
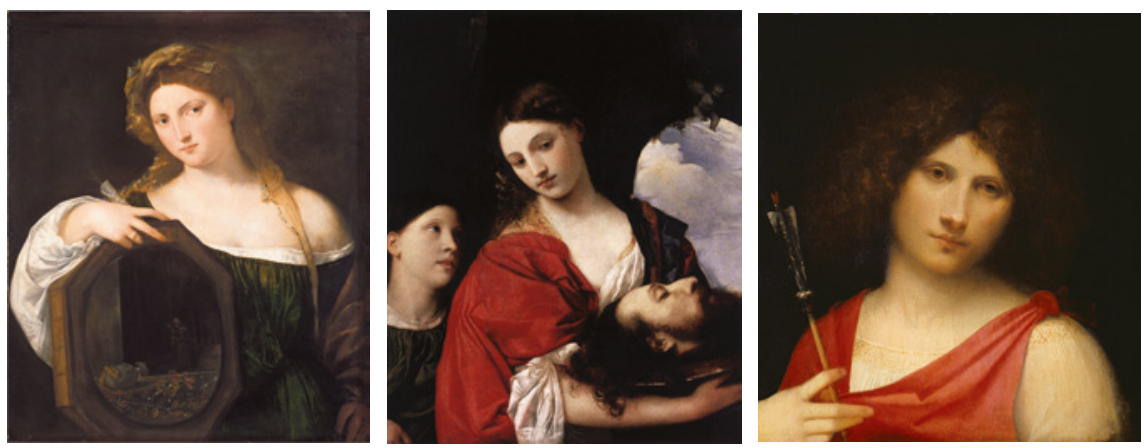

FIgURE 12.40 Titian, Vanitas; Munich, Alte Pinakothek.

FIGURE 12.41 Salome with the head of St John the Baptist; Rome, Gallerie Doria-Pamphilj.

FIGURE 12.42 Attributed to Giorgione, St Sebastian with an arrow; Vienna, Kunsthistorisches Museum.

The list includes several other of such 'portraits', four of women from classical mythology and history by a painter called 'Giulio Fiammingo' and four unidentified ones by 'Polidoro' (the Venetian Polidoro da Lanciano rather than Polidoro da Caravaggio), 'Rosso Veneziano' (perhaps Giovanni Rossi, known as Giovanni da Mel, $\dagger$ 1549?) and by Titian. Very interesting are four small 
anonymous portraits depicting contemporary artists, Michelangelo, Bandinelli, Andrea del Sarto and Titian, which implies Strada's conscious admiration for these great masters of the Italian Renaissance. A portrait of Virgil, Mantua's most illustrious son, by 'Licinio', reflects Strada's patriot pride as well as his love for classical poetry and learning: most likely it was an explicit commission from Strada's Vienna colleague, Giulio Licinio, rather than an existing painting by Giovanni Antonio da Pordenone or Bernardino Licinio he had chanced to pick up.

Most interesting is a painting attributed to Titian that is explicitly indicated as 'old'. It was a 'Tafel', a panel instead of a canvas, was set in a gilt frame and represented Judith and Holofernes. Possibly it was (a version of?) the Salome with the head of St John the Baptist now in the Galleria Doria-Pamphilj in Rome [Fig. 12.41]. The term 'old' here implies that it was no recent work, that it looked 'old-fashioned', so it must have been an early work of Titian, from the same period as the one other painting in the list that is described as old, 'an old picture made by Giorgio da Castelfranco, with two figures'. It is very tempting to identify the latter painting with Giorgione's Two figures in a Landscape in the National Gallery in London, also known as Il tramonto [Fig. 12.43].100

In contrast to these 'old' paintings are two paintings that must have been quite new, since they were by Niccolò Frangipane, one of the lesser gifted pupils of Titian: a small picture of the Judgment of Paris and a picture of 'einer Musica'. The latter was a specialism of Frangipane, and it is tempting to identify this particular one with the large Satire on the performance of a madrigal, in a private collection in Belgium or with one of various other versions which have appeared in the market recently. ${ }^{101}$ [Fig. 12.44] The madrigal in question, Bella guerriera mia, on a text from Pietro Bembo's Rime, set to music by Orlando di Lasso, is completely readable in the painting. Of course Lasso was the musical superstar of his generation, and his work was constantly reprinted; nevertheless, as Duke Albrecht's court composer he was a personal acquaintance of both Strada and Stopio (who provided the text for one of his motets) and repeatedly visited Venice himself. A painting such as this may well have been inspired by these Bavarian connections, even if it was not explicitly commissioned for a Bavarian patron.

100 Inv. nr. NG 6307. The figures have been interpreted as St Roch having his leg bound by St Gothardus; the St George fighting the dragon in the middle ground of this painting is a nineteenth-century addition.

101 It was the subject of a fascinating article by Bert Meijer (Meijer 1972-193), who also reconstructed Frangipane's biography (Meijer 1972). Other versions of this painting were included in the catalogues of sales at Munich (Hampel, 2009-06-26), London (Christie's, 2015-04-30) and Vienna (Dorotheum, 2916-10-18). 

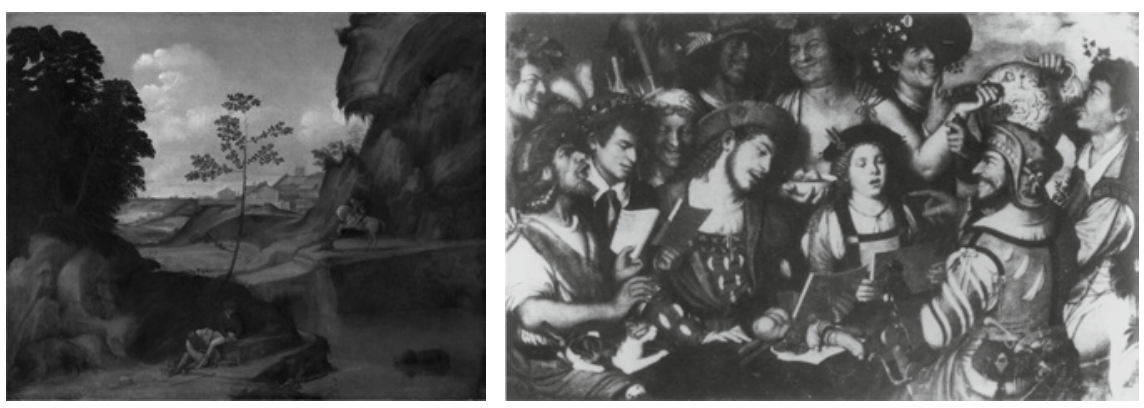

FIGURE 12.43 Giorgione, Il tramonto; London, National Gallery.

FIGURE 12.44 Niccolò Frangipane, Satire on the performance of a madrigal, private collection.

\subsubsection{The 'Kunstkasten' and Other Kunstkammer Items}

Though the heading of the list refers to paintings only, in fact it continues with a quantity of miscellaneous items of antiquarian and artistic character and a few typical Kunstkammer objects. The first object mentioned is the 'schöner kasten von einglegten holz', mentioned earlier: this was an intarsia cabinet or Kunstschrank, decorated and filled with small antique sculptures or fragments. Principal items were the portrait heads of Philip of Macedon, of his son Alexander the Great and of Hannibal; a female head identified as 'Capuana'; and the small heads of 'two children, one of whom laughs, the other cries', all in marble. The cabinet moreover contained a number of other small antiquities: a bust of Faustina in marble, and one of Minerva in 'metal', probably bronze, as were the statuettes of Apollo, a male and a female Satyr and two horses. Two 'Piramiden von Marmor' were probably marble obelisks topping the cabinet. It has been noted above that the presence in this Kunstschrank of the heads of the crying and laughing children relates this list to the earlier inventory of the Bussoni collection, which is likewise preserved in Munich and can be associated with Strada. This strongly suggests that it was Strada himself who had bought these sculptures and then commissioned this sumptuous piece of furniture to house some of the smaller antiques he had acquired.

This 'Kasten' must have been similar in intention-though not quite in size and splendour- to the Stipo Farnese, constructed in 1578-1579 to house the smaller antiquities collected by Strada's old patron, Cardinal Alessandro Farnese, after a concept of Strada's colleague, the learned antiquary and historian Fulvio Orsini [Fig. 12.45].102 Another example was the splendid cabinet designed by Francesco Capriani da Volterra in which Cesare Gonzaga housed

102 Ecouen, Musée National de la Renaissance; cf. Fornari Schianchi/Spinosa 1995, pp. 56-57. 

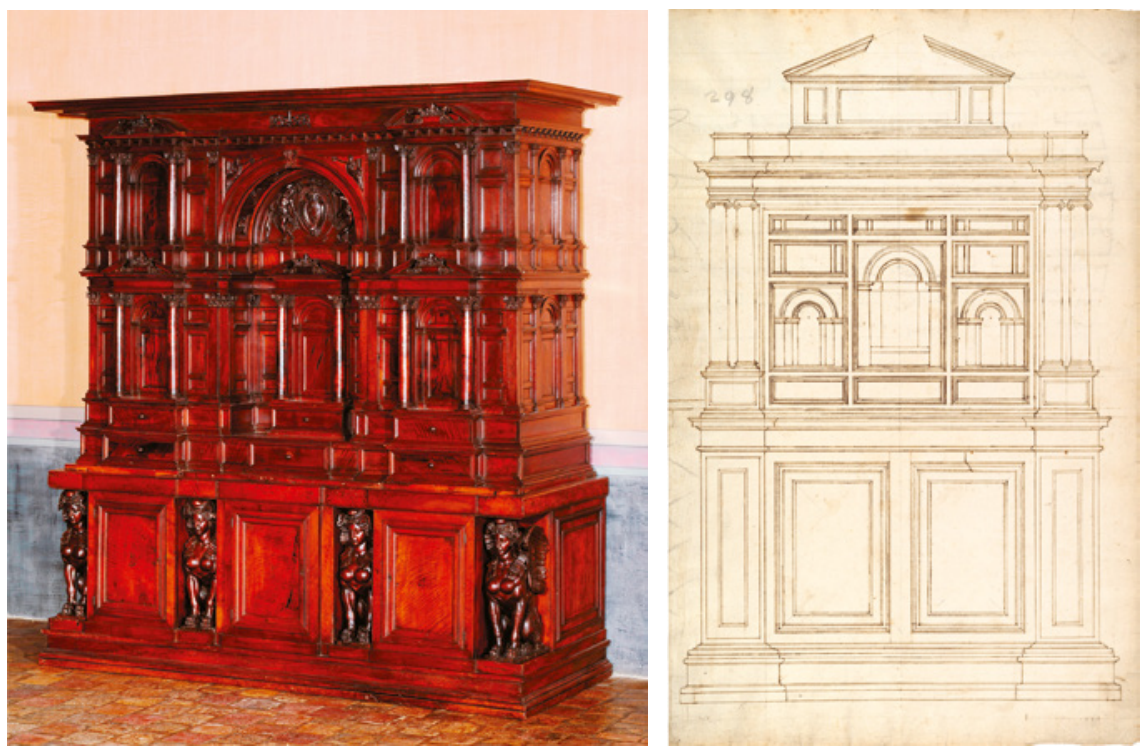

FIGURE 12.45 Flaminio Boulanger, the Stipo Farnese, conceived by Fulvio Orsini to house part of Cardinal Alessandro Farnese's antiquities, 1578-1579; Ecouen, Musée de la Renaissance.

FIGURE 12.46 Anonymous, drawing of a monumental cabinet, ca. 1560-1570; New York, Metropolitan Museum.

part of his celebrated collection of antiquities. From the account Strada presented to Duke Albrecht we know that he commissioned a set of drawings of what in the German translation of his account is called the 'Schreibtisch' of Cesare Gonzaga. ${ }^{103}$ The term Schreibtisch, literally 'writing desk', was probably the translation of Strada's 'scrittoio' or even 'studiolo'. Both of these terms could refer to a piece of furniture having a more ample function than purely administrative and literary pursuits, often providing space for coins, gems, small antiques, naturalistic objects and other interesting or valuable collectibles. In this case the object in question doubtless was the sumptuous coin cabinet described by Vasari as the 'studiolo fatto per le medaglie, il quale ha ottimamente d'ebano e d'avorio lavorato un Francesco da Volterra'.104 The fact that this object was made by a craftsman who was also a gifted architect suggests that it was closely akin to the later Stipo Farnese. It must have looked somewhat like the one documented in two drawings in the so-called Scholz Scrapbook in the Metropolitan Museum datable to the 1560 . These drawings

\footnotetext{
103 BHStA-LA 4853, fols. 16-20, published in Stockbauer 1874, pp. 34: 'Um den abriss des Don Caesars Schreibtisch v 8'.

104 The description of Cesare Gonzaga's stipo in Vasari-Milanesi 19o6, VI, pp. 489-490.
} 

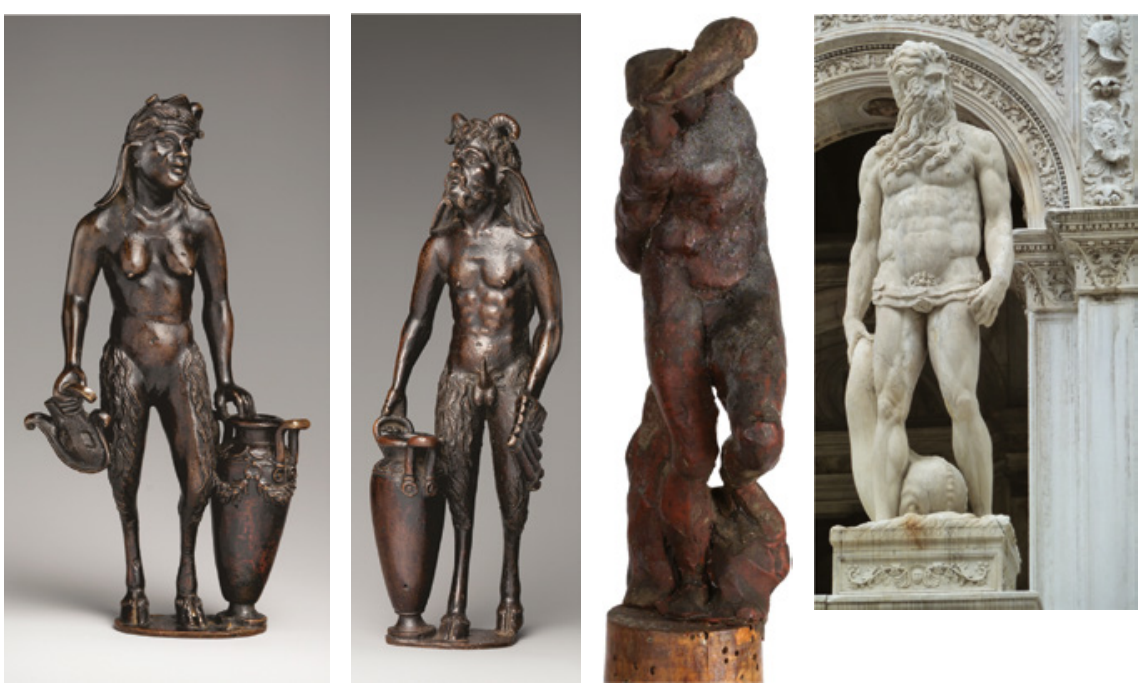

FIGURES 12.47-12.48 Andrea Briosco, detto il Riccio, bronze statuettes of a satyr and a satyress; New York, Metropolitan Museum.

FIGURE 12.49

Michelangelo, wax study for the young slave for the tomb of Pope Julius ii, London, Victoria and Albert Museum.

FIGURE 12.50 Jacopo Sansovino, Statue of Neptune; Venice, Palazzo Ducale.

show the architectural splendour of such cabinets and demonstrate that they were more often documented in such measured drawings [Fig. 12.46]. ${ }^{105}$

Doubtless Cesare Gonzaga's cabinet was the immediate source of inspiration for Strada's 'schöner Kasten'. Its inclusion in the list suggests a considerable time span between this document and the inventory of the Bussoni collection. Strada needed to bring together a quantity of suitable small antiquities to include in his 'Kasten'. Then he needed to order or, more likely, himself prepare a design for the cabinet, and find a cabinetmaker capable of meeting his doubtless ambitious demands. Of course this all might have been done during Strada's succeeding visits to Venice between 1566 and 1569 , in conjunction with the small coins cabinets he ordered for Duke Albrecht, but it is equally possible that he had it made at leisure when back home in Vienna.

In addition to the marble sculptures included in the Kunstschrank, the list mentions a gesso head of Pythagoras, perhaps a cast after the Antique, and a few statuettes. Three bronze statuettes of a Hercules and of two satyrs may

105 New York, Metropolitan Museum, Scholz Scrapbook fol. 298a-r., acc. nr. 49.19.39, and 298br., acc. nr. 49.19.40, showing an elevation and a detail of the cabinet; published in D'Orgeix 2001, p. 187 and p. 192, Fig. 47. In view of the apparent fame of Cesare Gonzaga's cabinet, it is not impossible that this drawing may document it. According to Stopio's Mantuan correspondent Strada also commissioned a three-dimensional model of the Palazzo del Te from Capriani himself (BHStA-LA 4852, f. 130; cf. above, n. 82). 
have been either antique or modern: one thinks of something like the couple of satyrs from the workshop of Andrea Riccio in the Metropolitan Museum [Figs. 12.47-12.48]. A small bronze of a man laying his hand on his head was indicated as being by 'Buonarota', but probably was after Michelangelo rather than in his own hand. It may have been the cast of a study similar to the wax model preserved in the Victoria and Albert Museum [Fig. 12.49], but more likely was a small bronze replica of one of the slaves for Michelangelo's tomb for Pope Julius II. The most interesting objects are four 'figures' in clay or terracotta made by one 'Antonella da Mantua' and a clay or terracotta figure of Neptune by Jacopo Sansovino, perhaps a study for the Neptune on top of the Scala dei Giganti in the Palazzo Ducale in Venice [Figs. 12.50].

Apart from these sculptures the list mentions some curiosities, typical Kunstkammer objects, such as a mirror in a richly wrought frame decorated with alabaster plaques and gilt medallions, an Arabic 'Rauchgeschirr' ('smoking appliance')' (perhaps an early example of a hookah?), 'a round mirror with which the Egyptians used to blind their enemy' and two 'maritimo Ainkirn', narwhal's tusks interpreted as the horns of a unicorn. A quantity of coins and medals mentioned probably consisted of doubles of Strada's own collectionit can hardly refer to his huge collection of ancient coins, which he probably would not have offered for sale. It is interesting that these were mounted in lead or ebony rings; perhaps they were at least in part modern portrait medals, rather than ancient coins.

\subsection{Conclusion}

In view of the relative rarity in Vienna of classical antiquities, the monumental Kunstschrank or collector's cabinet and the quantity and the interest of the ancient coins that were probably housed in its various compartments would have appealed at least to the educated among Strada's visitors. Though perhaps not very large, the collection of paintings on display was quite prestigious, including a number of large and splendid paintings by the greatest names of contemporary Venetian painting. If the two Veronese paintings now in the Frick Collection can be considered representative for Strada's cabinet of pictures, it must have made a big impression on his visitors. That such material was proposed to German patrons, the assumption that they would be interested in it, demonstrates the cosmopolitan attitude and the awareness of recent artistic developments in Italy prevalent both at Munich and at the Imperial court. Even without taking his own collection in account, Strada's expertise and his personal connections with several of these artists must have been an important factor in creating that awareness. 